\title{
The genus Bolboschoenus in Iran: taxonomy and distribution
}

\author{
Mohammad Amini Rad, Zdenka Hroudová and Karol Marhold \\ M. Amini Rad (aminirad2000@yahoo.co.uk), Dept of Botany, Iranian Research Inst. of Plant Protection, PO Box 1454 Tehran 19395, Iran. \\ - Z. Hroudova', Inst. of Botany, Academy of Sciences of the Czech Republic, CZ-252 43 Prihonice, Czech Republic. - K. Marhold, Inst. of \\ Botany, Slovak Academy of Sciences, Dúbravska' cesta 9, SK-845 23 Bratislava, Slovak Republic. KM also at: Dept of Botany, Faculty of Science, \\ Charles Univ., Benátská 2, CZ-128 01 Praha, Czech Republic.
}

\begin{abstract}
A revision of the Iranian Bolboschoenus was made based on studies of herbarium material and cultivated plants. Fruit features (fruit shape and pericarp anatomy) were used as the main distinguishing characters; style branching, inflorescence structure and the colour of floral scales were considered as accompanying distinguishing characters. The following taxa were recognized: Bolboschoenus glaucus (Lam.) S. G. Sm., B. affinis (Roth) Drobov, B. schmidii (Raymond) Holub, B. planiculmis (F. Schmidt) T. V. Egorova and B. maritimus (L.) Palla. Taxonomical difficulties, especially in the B. affinis group and B. maritimus are discussed. Bolboschoenus glaucus was found in all of the phytogeographical regions of Iran, and it is more frequent than any other Bolboschoenus species. Bolboschoenus planiculmis is very rare in the IranoTuranian and Hyrcanian regions and grows only in human-influenced habitats; it might be introduced as a weed in rice fields. Bolboschoenus maritimus, B. affinis and B. schmidii occur in the Irano-Turanian region only rarely. Bolboschoenus maritimus reaches the southeastern border of its distribution area in this region. All these species typically grow at higher altitudes. Great morphological variability in inflorescence structure was found in some species (especially in B. glaucus), which may be partly explained as a response to habitat conditions and partly by genotypic diversity.
\end{abstract}

The genus Bolboschoenus (Asch.) Palla is widely distributed around the world, comprising about 15 species (Browning and Gordon-Gray 2000, Tatanov 2007). The circumscription of numerous species is difficult due to morphological variation associated with the poorly understood influence of habitat conditions and likely interspecific hybridization. The taxonomy and distribution of Bolboschoenus has been studied in Africa (Browning and Gordon-Gray 1993, 1999, Browning et al. 1998), North America (Browning et al. 1995), Australia and New Zealand (Browning et al. 1997a) and in Europe (Browning et al. 1996, 1997b, Marhold et al. 2004, Hroudová et al. 2007a). Egorova and Tatanov (2002, 2003) and Tatanov (2003a, b, 2004, 2005, 2007) published surveys of Bolboschoenus in the former Soviet Union (including central Asia and the Caucasus) and Hayasaka and Ohashi (2002) studied the genus in Japan. An overall study of this genus in Asia is lacking.

The first record of the genus Bolboschoenus from the area studied here (in a wide sense) is found in 'Flora orientalis' by Boissier (1882, p. 384). He reported Scirpus maritimus ( $\equiv B$. maritimus) as being widespread in Baluchestan, which covers parts of the areas of current Iran and Pakistan. Parsa (1950) in 'Flora de l'Iran' reported S. maritimus in two formae: f. compactus and f. monostachys. Scirpus maritimus was also reported from Iran by Mobayen (1975). The possible occurrence of
Bolboschoenus glaucus in the 'Flora Iranica' area was mentioned by Kukkonen (1996), and consequently, Kukkonen (1998) presented three Bolboschoenus species in 'Flora Iranica' (also covering part of Pakistan): B. affinis, $B$. maritimus and B. glaucus. Only the first two (B. affinis and $B$. maritimus) were reported directly from Iran. In 'Flora of Pakistan', Kukkonen (2001) used fruit shape and anatomy as distinguishing characters, and recognized $B$. glaucus (representing specimens formerly identified as B. maritimus). Amini Rad (2003) reported B. glaucus for the first time for the flora of Iran. Recently, Amini Rad and Hroudová (2007) reported B. schmidii and B. planiculmis from Iran. In the current paper, we present the results of revisions of herbarium material (including a part of specimens listed in 'Flora Iranica'), complemented by plants collected in the field during the last decade, and the study of cultivated plants of B. glaucus, B. maritimus and B. schmidii collected in Iran. An identification key is included, and for each accepted species, nomenclature, synonymy, morphological description, habitat characteristics and distribution are given. The plant material available was limited by the sparse occurrence of wetlands in Iran, concentrated to river shores and lake districts, and scarcity of herbarium specimens; nevertheless, we hope this study will help to fill gaps in our knowledge of the distributions of Bolboschoenus species. 


\section{Material and methods}

Bolboschoenus specimens from Iran were studied in the Iranian herbarium collections IRAN and TARI, and in the European herbaria B, BRA, H, JE, M, PRA, W, and WU. Data on the habitats given on herbarium labels were used also for habitat characteristics. The material studied included also herbarium specimens revised by I. Kukkonen for 'Flora Iranica' (Kukkonen 1998); in the lists of studied specimens these are indicated by the abbreviation FIr (Flora Iranica), followed by the specimen number and species name as given in 'Flora Iranica'. Unfortunately, some specimens listed in 'Flora Iranica' were not available for our study. The publications Eig (1931-1932), Hedge and Wendelbo (1978), Jalili and Jamzad (1999) and Zohary (1963) were used as sources of information on Iranian phytogeographical regions for mapping of the distributions of the studied species.

The first author collected plants of all Bolboschoenus species from natural habitats in Iran, and recorded the habitat characteristics. Voucher specimens are deposited in herbarium IRAN, some duplicates also in PRA (see lists of specimens studied).

Bolboschoenus glaucus, B. maritimus and B. schmidii were further cultivated in the experimental garden of the Inst. of Botany of ASCR in Průhonice (Czech Republic), which allowed visualisation of their morphological variation and scoring the reliability of some distinguishing characters (plant height, proportion of upper leafless part of stem, number of spikelets) compared to herbarium specimens. Bolboschoenus maritimus and B. glaucus were cultivated from tubers brought from Iran by J. Sádlo and Z. Kaplan, and B. schmidii was cultivated from seeds of plants collected in Iran by M. Amini Rad. All plants were planted under the same conditions (in a mixture of sand and garden soil 1:2, water level kept approximately at soil surface). Voucher specimens of cultivated plants are deposited in herbarium PRA. Unfortunately, the number of cultivated plants was too low for statistical evaluation, and living plants of $B$. affinis and $B$. planiculmis from Iran were not available.

As the most important distinguishing characters are found in the achene shape and pericarp anatomy, only fully developed fruiting plants could be reliably identified and included in the list of localities. The following characters were taken into account in distinguishing the species: inflorescence structure (e.g. a compact inflorescence with mostly sessile spikelets or a branched inflorescence with numerous rays); colour of floral scales (equivalent to the colour of spikelets); style branching; achene shape; achene surface (honeycomb surface structure, cell outlines visible, or translucent cell walls); pericarp anatomy, studied on cross-sections of achenes (the proportions of the exocarp and mesocarp thicknesses).

\section{Key to Iranian species of Bolboschoenus}

1. Achenes with the pericarp formed by a thin exocarp layer and a thick sclerenchymatic mesocarp . . . . . 2 - Achenes with the pericarp formed by a well developed exocarp (with elongated cylindrical cells filled with air) and a thin sclerenchymatic

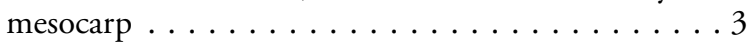

2. Inflorescence mostly branched, formed from a group of sessile spikelets and rays bearing single spikelets or fascicles of spikelets; floral scales light brown to rustybrown, frequently brownish-red or deep purplish-red; achenes with only a slightly developed edge on the abaxial side, plano-convex to subtrigonous in crosssection, $2.2-3.1 \mathrm{~mm}$ long, $1.4-1.7 \mathrm{~mm}$ wide; the exocarp slightly visible . . . . . . . . . B. glaucus - The inflorescence head-like, formed from one fascicle of sessile spikelets or with 1-2 rays bearing single spikelets; floral scales yellowish-white to light brown; achenes mostly with a conspicuous edge on the abaxial side, triangular in cross-section, 3.0-3.9 mm long, 1.9$2.5 \mathrm{~mm}$ wide; the exocarp layer thin but visibly developed. . . . . . . . . . . . . B. schmidii

3. Achenes concave on the abaxial side, biconcave or plano-concave; the exocarp approximately as thick as the sclerenchymatic mesocarp, thicker over the rounded angles than on the concave faces...... ........................ planiculmis - Achenes flattened or convex on the abaxial side, oval or plano-convex to subtrigonous; the exocarp thicker than the sclerenchymatic mesocarp . . . . . . . 4

4. Floral scales yellowish-white, yellowish-brown to light brown; styles predominantly bifid; achenes flattened to slightly convex on the abaxial side, oval to planoconvex . . . ............... affinis - Floral scales never yellowish-white, usually light brown to rust-brown; styles predominantly trifid; achenes convex on the abaxial side, plano-convex to subtrigonous . . . . . . . . . B. maritimus

\section{Bolboschoenus affinis (Roth) Drobov (1913, p. 89) (Fig. 1)}

Basionym: Scirpus affinis Roth in Roem. and Schult. (1817, p. 140).

Based on the same type: Scirpus maritimus subsp. affinis (Roth) Norl. (1972, p. 404). - Bolboschoenus maritimus subsp. affinis (Roth) Koyama (1979, p. 284).

Type: "In India orientali.". Lectotype designated by Tatanov (2007): Ex Ind.[ia] Orient.[ali], s.a., D.[edit], Roth 1816 (LE!). Epitype designated by Tatanov (2007): Ind.[ia] Or.[ientalis], Malabar [Kerala], Concan [Konkan, Maharashtra] etc., Regio trop., alt., s.a., Stocks, Law, etc. s.n. (LE!; isoepitypes: C, KW, LE, P).

Taxonomic synonyms: Scirpus strobilinus Roxb. in Carey and Wall. (1820, p. 222).

Based on the same type: Bolboschoenus strobilinus (Roxb.) V. I. Krecz. in Ovcz. (1963, p. 47).

Type: "A native of the soft, wet banks of the Ganges.", not seen.

- Bolboschoenus popovii T. V. Egorova (1967, p. 21). Type: "China, Kaschgaria, Bugur". Holotype: China, Kaschgaria, Bugur, 20 Jul 1929, M. G. Popov 795 (LE!).

Perennial plants, $30-55 \mathrm{~cm}$ tall. Rhizome creeping, 1-3 $\mathrm{mm}$ in diameter, bearing spherical or ellipsoid tubers, reddish-brown or brown. Stem sharply trigonous, with 


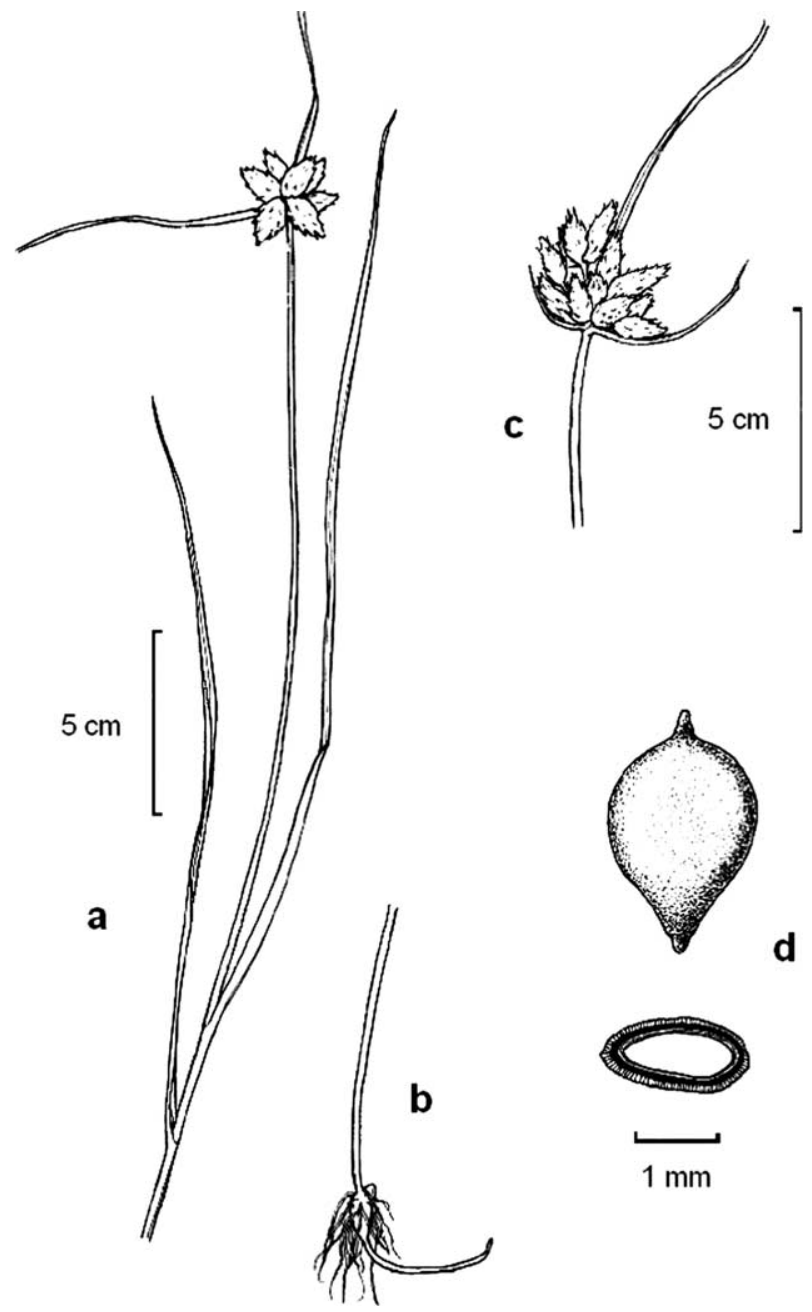

Figure 1. Bolboschoenus affinis. (a) the upper part of a flowering plant, (b) the lower part of a stem with tuber, (c) inflorescence, (d) achene (dorsal view and cross-section, with the sclerenchymatic mesocarp in black). Drawn from voucher specimens from Fars, Lake Maharlou, IRAN 35550 (a)-(b), Azerbaijan, Lake Rezaiyeh, IRAN 37225 (c), and Esfahan, Golpayegan, N Varzaneh, TARI 37853 (d). Del. Z. Hroudová.

concave sides, $1.5-2.5 \mathrm{~mm}$ in diameter, edges smooth, grooved with 5-6 nerves on one side, grey-green, nodded with elongated internodes. Leaves approximately equalling to stem length, situated on stem nodes; sheaths $6-10 \mathrm{~cm}$ long, yellow to brown, margin of scarious side straight; blades 2.0-7.5 mm wide, flat or sometimes folded, keeled, grey-green or green, margins smooth or slightly scabrous to the top. Inflorescence head-like, formed of a fascicle of 4-8 sessile spikelets, or composed of a central group of sessile spikelets and 1 or 2 rays 10 to $40 \mathrm{~mm}$ long, bearing 1 to 2 spikelets. Inflorescence supported by $2-3$ involucral bracts to $15 \mathrm{~cm}$ long. Spikelets (10-) 12-20 (-25) long and (4-) 8-10 mm wide, ovate, obtuse, sometimes oblong or ellipsoid, yellow-brown; glume-like bract $5-6 \mathrm{~mm}$ long; glume-like prophyll ca $4.0-4.5 \mathrm{~mm}$ long; floral scales 6-8 $\times 3-4 \mathrm{~mm}$, cymbiform, arista $1.0-1.5 \mathrm{~mm}$ long, frequently curved, margins scarious and nerveless, ciliate, yellow-white to yellow-brown, apex truncate and trifid; perianth bristles 4, caducous, unequal, shorter than achene; anthers (1.5-) 3.5-4.0 mm long; styles bifid, sometimes also trifid styles may be found in the same inflorescence. Achenes $2.5-3.0 \mathrm{~mm}$ long and $2 \mathrm{~mm}$ wide, obovate, flattened to slightly convex (rarely slightly concave) on abaxial side, plano-convex or slightly biconvex with round edges, rusty brown to dark brown, beak to $0.2 \mathrm{~mm}$, surface reticulate, glossy, surface cell walls frequently translucent causing visible cell network; pericarp (in cross-section) with well developed exocarp, sclerenchymatic mesocarp and endocarp; exocarp formed by one layer of cylindrical cells radially elongated and filled by air, exocarp layer often wider in angles than over flattened sides, exocarp thicker than mesocarp.

\section{Distribution and ecology}

Bolboschoenus affinis inhabits saline lakeshores and riversides. It is distributed from the southwestern part of European Russia through Iran, Afghanistan and Pakistan to central Asia, India, south eastern Asia and China (DeFilipps 1980, Tatanov 2007). In Iran, its area is limited to river and lake districts in north western to southern Iran within the Irano-Turanian region, only one locality is known in northern Iran in the Hyrcanian region (Fig. 2).

\section{Notes}

According to Tatanov (2007), both B. affinis and $B$. popovii occur in Iran and their distribution areas overlap there. At the same time, morphologically intermediate plants of probable hybrid origin are found in Iran, making the differentiation of the species difficult (I. V. Tatanov pers. comm.). Following Egorova (1967, 1976) and Tatanov $(2004,2005,2007)$, the differentiation between B. affinis and B. popovii should be based on the following character states: In $B$. affinis inflorescence is more loose, sometimes compound (umbelliform); spikelets are 1.8$2.3 \mathrm{~cm}$ long, strobile-shaped, broadly ovate; colour of floral scales (spikelets) is either brown, light brown, grayyellowish, grayish-light brown or yellowish, purple striped; stigmas number is 2 ; fruit shape is slightly biconcave or flat on both sides, (1.7-) 1.8-2.0 mm wide, elongate-obovate with truncate base, whereas in $B$. popovii inflorescence is compact, formed of closely sessile spikelets; spikelets are (1.0-) 1.3-1.5 (-1.8) cm long, robust, cask-shaped, rounded-ovate, acuminate; colour of floral scales is yellowish-whitish, neither purple-striped nor slightly purple-striped; stigmas 2; fruit shape is flat-convex to unequally biconvex, broadly obovate, rarely oval, with conical or broadly-conical basis. Nevertheless, the differentiation between these two species appeared to be very uncertain in the Iranian plants studied by us; some plants of intermediate character were found, as well as plants with characters of both species combined (e.g. loose inflorescence with some spikelets on rays, yellowish-whitish colour of spikelets and flat-convex fruit shape). Therefore, we decided to include $B$. popovii in a widely circumscribed B. affinis.

In 'Flora Iranica' (Kukkonen 1998), B. schmidii was included in B. affinis. However, B. schmidii differs from $B$. affinis by trigonous fruits with thin exocarp and thick 


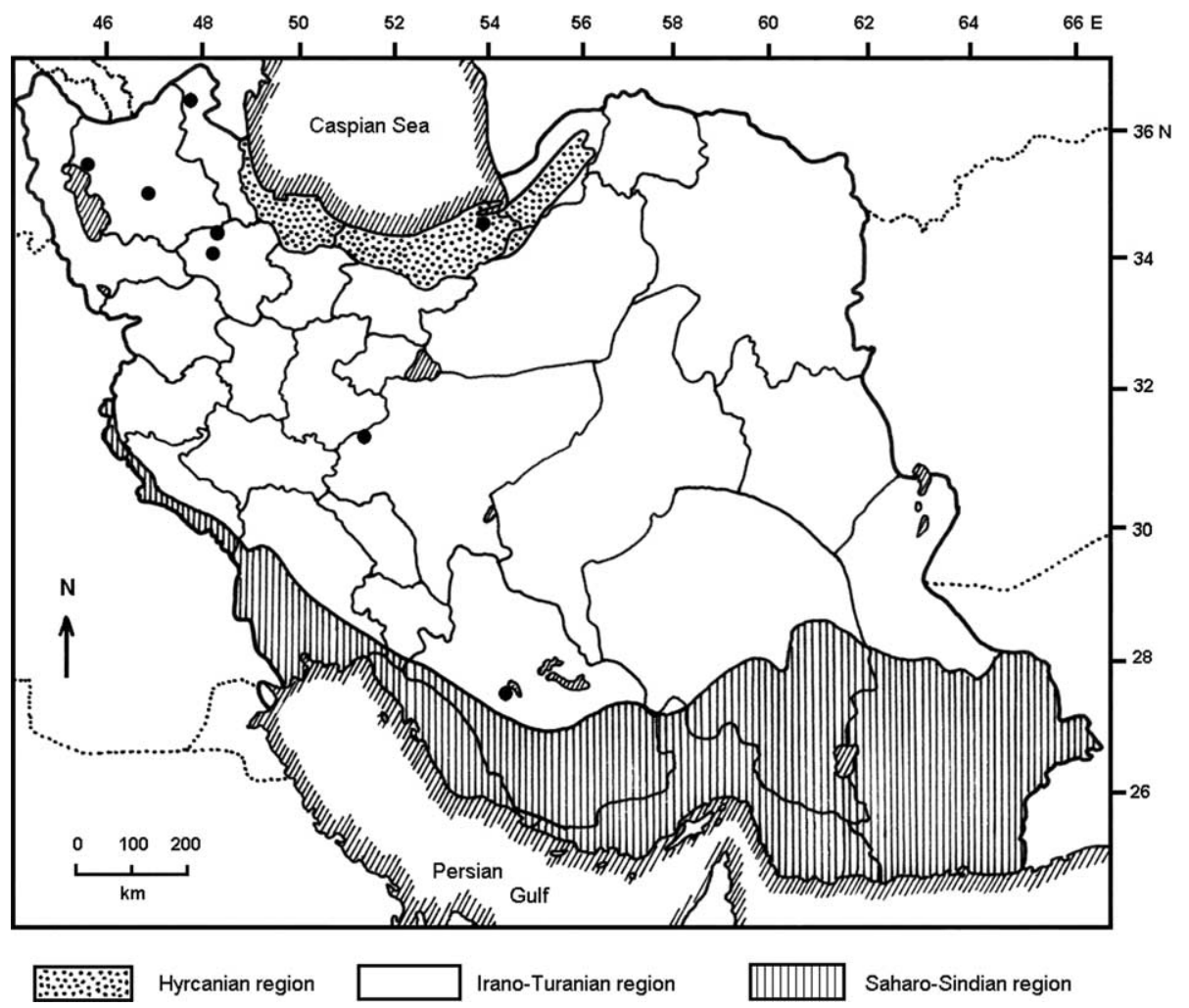

Figure 2. The distribution of Bolboschoenus affinis in Iran.

sclerenchymatic mesocarp layers (Tatanov 2003a). Based on the differences in fruit shape and pericarp anatomy revealed also in our study we distinguish B. schmidii as a separate taxon. The characters stated above are important as distinguishing ones also for other taxa of the genus Bolboschoenus (Browning and Gordon-Gray 2000).

\section{Specimens examined}

Mazandaran: Behshahr, ca $10 \mathrm{~km}$ north of Galeh-Payan, shore of Gulf of Gorgan, 15 Aug 1987, Zehzad (Shahid Beheshti Univ., Dept of Biological Sciences Herbarium 87364, IRAN 52991). Azerbaijan: Moghan, between Ali-Reza-Abad and Gharaaghadj, $300 \mathrm{~m}$ a.s.l., 23 May 1971, Iranshahr (IRAN 29414; FIr 14796-E as B. affinis); Lake Rezaiyeh, Bandar-e Sharafkhaneh, 7 Nov 1978, Assadi and Salehi (TARI 31976), 23 Jul 1990, Assadi et al. (TARI 68463), 27 Aug 2003, Amini Rad and Eskandari (IRAN 37225 , rev. by I. Kukkonen as B. affinis); Sharafkhaneh, 10 Oct 1948, Behboudi and Aellen (IRAN 29413; FIr 6067$\mathrm{E}$ as B. affinis); between Zanjan and Mianeh, $89 \mathrm{~km}$ to Mianeh, Ghezel Ozan margin, 1430 m a.s.l., s. d., Zehzad et al. (TARI 70470); about $10 \mathrm{~km}$ southeast of Mah Neshan, $1300 \mathrm{~m}$ a.s.l., 29 Sep 1987, Assadi and Akhani (TARI 61190); ca $60 \mathrm{~km}$ southeast of Tabriz, on the road from Zanjan to Tabriz, shallow lake shore, $1900 \mathrm{~m}$ a.s.l., 19 Aug 1972, P. Uotila (H 1700906, 1653319; FIr 19480, as B. affinis). Esfahan: Golpayegan, northern Varzaneh, 1900 $\mathrm{m}$ a.s.l., 21 Oct 1981, Mozaffarian and Karimi (TARI 37853). Fars: $25 \mathrm{~km}$ of Shiraz, Lake Maharlou, 30 Apr 2003 , Amini Rad, Sonboli and Tehrani (IRAN 35550, rev. by I. Kukkonen as B. affinis; H 1723934).
Bolboschoenus glaucus (Lam.) S. G. Sm. (1995, p. 101) (Fig. 3)

Basionym: Scirpus glaucus Lam. (1791, p. 142).

Type: "Senegal". Holotype: Senegal, s.a., Roussilon s.n. (P-Herb. Lamarck 673/14; n.v.).

Taxonomic synonym: Scirpus macrostachys Willd. (1809, p. 78) nom. illeg., non Scirpus macrostachyos Lam. (1791, p. 142).

Based on the same type: Scirpus maritimus $\gamma$ [var.] macrostachys Vis. (1842, p. 109). - Scirpus maritimus f. macrostachys (Vis.) Nilsson (1901, p. 673). - Bolboschoenus macrostachys (Vis.) Grossh. (1928, p. 145). - Bolboschoenus maritimus var. macrostachys (Vis.) T. V. Egorova (1976, p. 94). - Bolboschoenus maritimus subsp. macrostachys (Vis.) Soják (1983, p. 19).

Type: "Habitat in Italia". Lectotype designated by Tatanov (2007): s. loc., s.a., Savi s.n. (B-Willd. 1236! [planta media]). Epitype designated by Tatanov (2007, p. 70) referring to Marhold et al. (2006, p. 104, 109): Italy, Vallo, 1963, R. Wagner s.n. (GJO!).

Perennial plant, (15-) 23-75 $(-100) \mathrm{cm}$ tall. Rhizome creeping, 1.5-3.0 $(-4.0) \mathrm{mm}$ in diameter, bearing underground spherical to elliptical tubers $15-20 \times 12-15 \mathrm{~mm}$ in size. Stem sharply trigonous, with flat or slightly depressed sides, $1.5-2.5 \mathrm{~mm}$ in diameter, light green to grey-green, smooth or scabrous towards the top, nodded. Leaves shorter to longer than stem; sheaths $3-10(-15) \mathrm{cm}$ long, yellow-brown, green to brown or reddish-brown; blades 3.5-6.5 $(-10) \mathrm{mm}$ wide, flat or folded, keeled, 


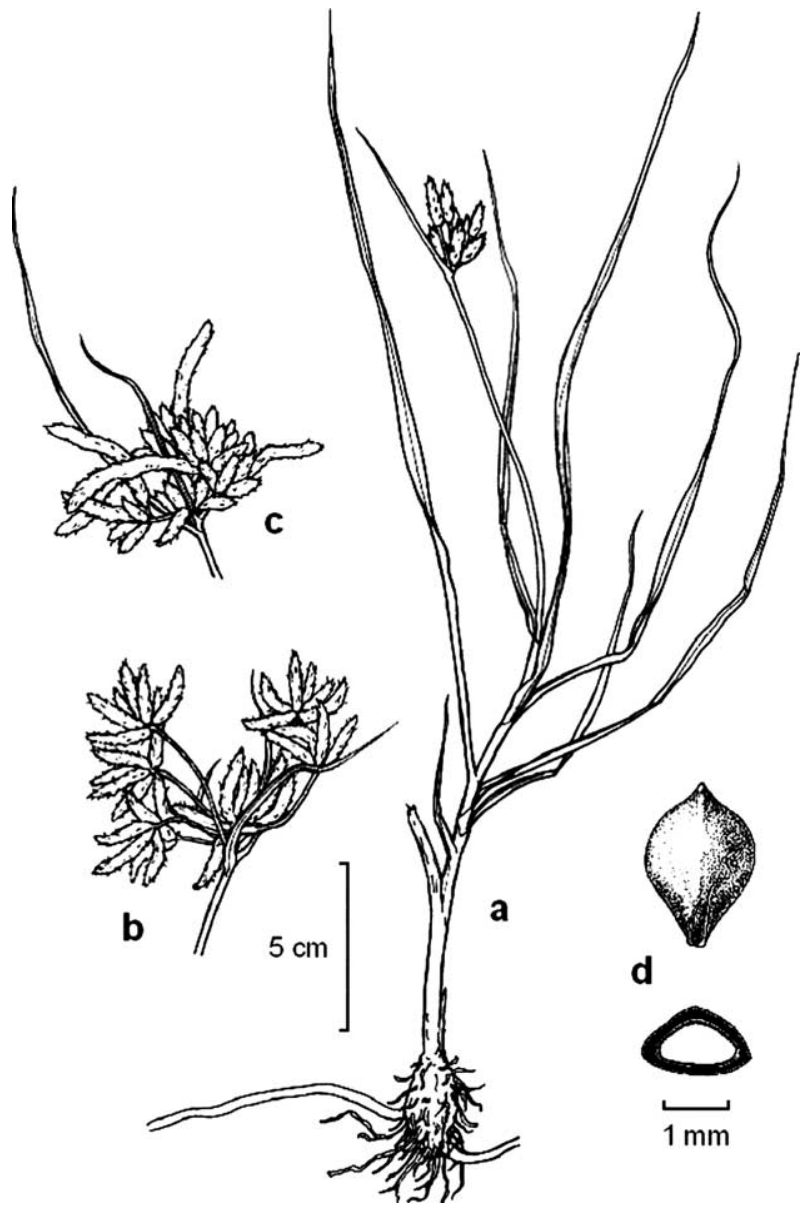

Figure 3. Bolboschoenus glaucus. (a) plant from a dry habitat with a compact inflorescence, (b) typical branched inflorescence, (c) inflorescence with several extremely long spikelets, (d) achene (dorsal view and cross-section, with the sclerenchymatic mesocarp in black). Drawn from voucher specimens from Hamadan, Kuh Alvand, IRAN 29415 (FIr 66570-E) (a), Kordestan, Lake Marivan, IRAN 32500 (b), Khuzestan, Shoush, IRAN 43970 (c), and Azerbaijan, Mah Neshan, the river Ghezel-ozan, TARI 61191 (d). Del. Z. Hroudová.

smooth or scabrous near the top. Inflorescence usually a richly branched anthelodium consisting of a central group of $6-12$ sessile spikelets and 4-8 rays bearing fascicles of 2-7 (-10) spikelets or (rarely) single spikelets; numbers and length of rays, number of spikelets in fascicles on rays are very variable; involucral bracts $2-3,14-16 \mathrm{~cm}$ long. Sometimes 1-2 raylets with single spikelets forming small a anthelodium of second order on rays may be found. Spikelets on rays $10-40 \mathrm{~mm}$ long and $3-6 \mathrm{~mm}$ wide, oblong-elongated or ovate; sessile spikelets $14-40 \mathrm{~mm}$ long and 3.5-6.0 mm wide, oblong or orbicular; glume like bract $4.5-5.0 \mathrm{~mm}$ long, arista to $1 \mathrm{~mm}$; glume like prophyll to $4 \mathrm{~mm}$ long; floral scales $5.0-7.5 \times 3.5 \mathrm{~mm}$ in size, cymbiform, light brown, reddish-brown to deep purplish-red, with curved arista to $1.5 \mathrm{~mm}$ long, margins scarious and nerveless, ciliate, barbed, apex truncate and slightly trifid; perianth bristles 4-6, shorter to longer than achene, partly caducous (long bristles), partly persistent (frequently short bristles); anthers (2-) 2.5-3.0 (-4.0) mm long; style trifid. Achenes small, $2.0-3.1 \mathrm{~mm}$ long and 1.5-2.2 mm wide, obovate, convex on abaxial side with slightly marked edge to trigonous, with beak to $0.1 \mathrm{~mm}$, light or rust brown to dark brown, surface smooth, fine reticulate; pericarp in cross-section with a thin exocarp formed of one layer of more or less isodiametric cells, a thick layer of sclerenchymatic mesocarp and a thin sclerenchymatic endocarp.

\section{Distribution and ecology}

Bolboschoenus glaucus is a freshwater plant, occurring frequently along streams (brooks, river shores, boulder flood-plain), on lake shores, in semi-desert swamps and in any other marshes. Its localities are frequently connected with human settlements (villages, marshy hay fields, meadows, pastures). Bolboschoenus glaucus is distributed in temperate to subtropical zones around the Mediterranean Sea (southern Europe, northern Africa), and in sub-Saharan Africa (Browning et al. 1998, Hroudová et al. 2007a). The westernmost localities are found in Portugal (Hroudová et al. 2007b). From Europe the area of B. glaucus continues eastward to southern Ukraine, southern Russia, Turkey, central Asia, Iran, Iraq, Afghanistan, Pakistan, India and China (Kukkonen 1996, 2001, Egorova and Tatanov 2002, Amini Rad 2003, Tatanov 2007). It has been introduced to North America. This species appears to be the most frequent of all of the Bolboschoenus taxa in Iran, distributed over many provinces and in all phytogeographical regions (Fig. 4). Bolboschoenus glaucus is distinguished by its presence in a considerable proportion of habitats of secondary human-influence, which might indicate the possible use or spread by human activities.

\section{Notes}

Bolboschoenus glaucus is quite variable in its inflorescence structure. It has often a very rich inflorescences with numerous rays differing in length (from 1 to $10 \mathrm{~cm}$ ) and numerous sessile spikelets as well as spikelets on rays. In some cases small anthelodia of secondary order can be found on rays. In other cases, spikelet-poor inflorescences formed of only sessile spikelets (Amini Rad 2003, Fig. 2) may arise, in extreme cases formed of only one spikelet. The formation of these morphotypes may be influenced by habitat conditions (shortage of water or nutrient supply) and may reflect year-to-year weather fluctuations. On the other hand, some differences between populations in the length of spikelets and rays may be fixed in genotypes (Marhold et al. 2006). As noticed by Browning et al. (1998), in some plants of B. glaucus, the stem internodes may be strongly shortened, forming only 'basal' leaves. Such short plants appear to have culms leafless between the 'basal' leaves and the inflorescence. Such plants were also found in Iran, e.g. Hamadan, Kuh Alvand, 7 Jun 1965, Babaii (IRAN 29415). Glume colour (and thus colour of spikelets) may vary as well, from deep purple to reddish, rusty brown till light ochre or yellowish. Red or purple glume colour is typical of $B$. glaucus, but possible hybridization with other species (B. affinis or B. maritimus) might probably influence the colour of spikelets. Besides, glume colour may change during drying in herbarium collections. 


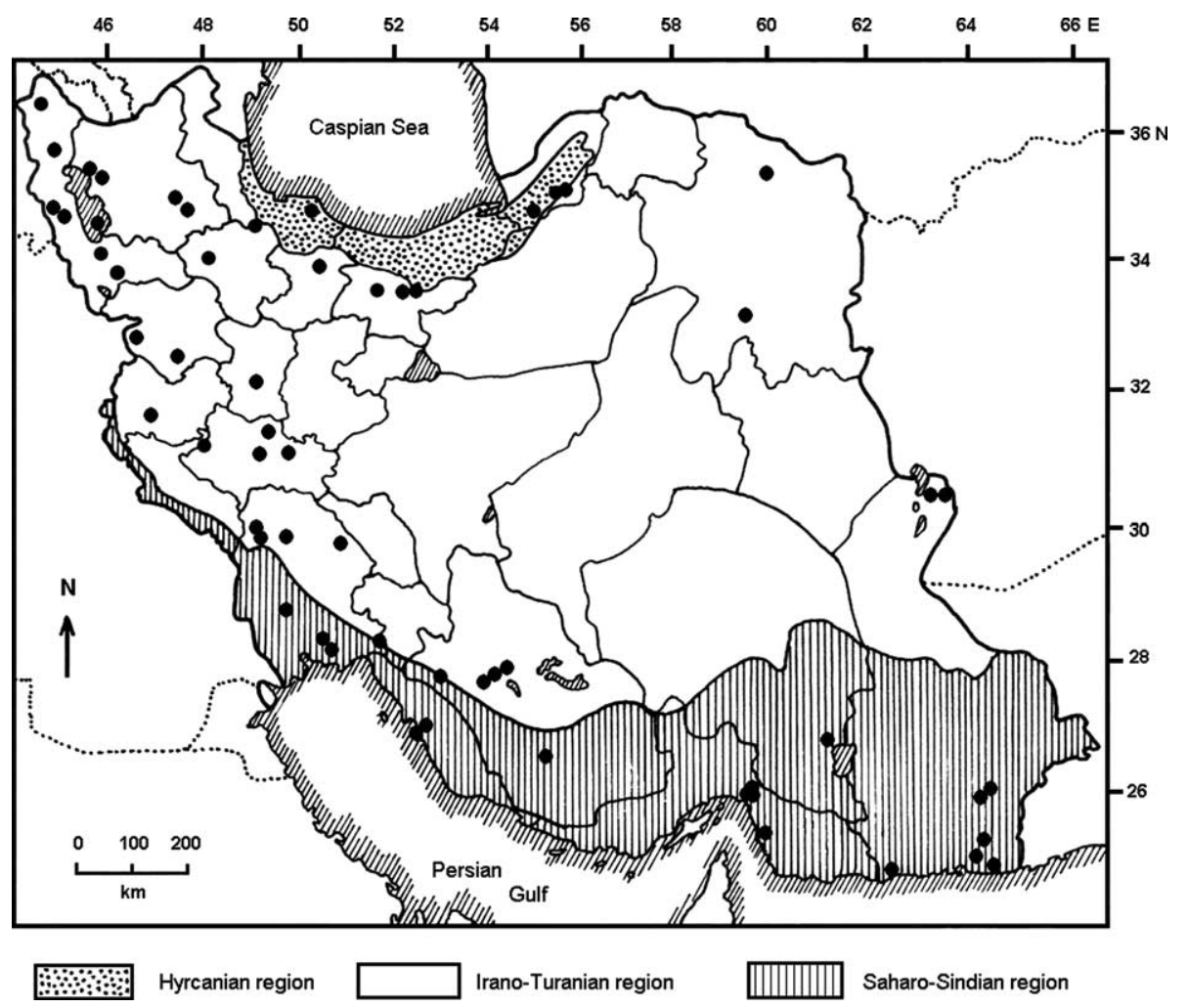

Figure 4. The distribution of Bolboschoenus glaucus in Iran.

\section{Specimens examined}

Gorgan: Ramian, 25 Jun 1952, Iranfar (IRAN 32439); Gorgan, Mirmahaleh, ca 60 m a.s.l., 10 Jun 1956, F. Schmid (W19289; FIr 6036, 6046, as B. maritimus); ca $10 \mathrm{~km}$ west of Shahpasand, roadside, ditch and margin of the ditch, $25 \mathrm{~m}$ a.s.l., 29 Apr 1972, I. Kukkonen (H 1654350, 1700904; FIr 5656, as B. maritimus). Gilan: Astaneh-e Ashrafie, 29 Jul 2002, Amini Rad and Tehrani (IRAN 34430, rev. by I. Kukkonen as B. glaucus; $H$ 1717430) [the latter specimen is an intermediate plant with fruits of size and shape as in $B$. maritimus, but with pericarp anatomy as B. glaucus - possible hybrid?]. Azerbaijan: $5 \mathrm{~km}$ of Ghareh-Chaman to Mianeh, 21 Aug 2003, Amini Rad and Eskandari (IRAN 37288, rev. by I. Kukkonen as B. glaucus); $9 \mathrm{~km}$ of Khoy to Ghotour, 1250 m a.s.l., 20 Aug 2007, Amini Rad and Pahlevani (IRAN 48867); $15 \mathrm{~km}$ of Oroumyeh, Didan village, 26 Aug 2003, Amini Rad and Eskandari (IRAN 37220, rev. by I. Kukkonen as B. maritimus); $5 \mathrm{~km}$ west of Mianeh, 18 May 1997, Kaplan and Sádlo (IRAN 48869, PRA); Oroumyeh, Kabudan Island, alt. 1320-1580 m a.s.l., 18 Jun 1977, Moussavi and Zargani (IRAN 29419, W 933; FIr 36623-E, as B. maritimus); Zanjan, Tarom, Gilvan, Sep 1994, Padasht (IRAN 51915); Sharafkhaneh, 10 Oct 1948, Behboudi and Aellen (IRAN 29418; FIr $6065-\mathrm{E}$, as B. maritimus) 15 miles $(24 \mathrm{~km})$ southeast of Mahabad, $5000 \mathrm{ft}$ a.s.l., 21 May 1962, Furse (IRAN 17245, W 12283; FIr 2183, as B. maritimus); between Oroumyeh and Ghasemlou, Tomater village, $1160 \mathrm{~m}$ a.s.l., 26 Jul 1990, Izadpanah and Taheri (TARI 68241); between Ilakhji and Shabestar, $1300 \mathrm{~m}$ a.s.l., 28 Sep 1992, Hamzeh'ee and Asri (TARI 71840); ca $10 \mathrm{~km}$ southeast of Mah Neshan, Ghezel-ozan river margin, $1300 \mathrm{~m}$ a.s.l., 29 Sep 1987, Assadi and Akhani (TARI 61191); ca $10 \mathrm{~km}$ southeast of Maku, on the road from Tabríz to Bazargan, meadow, rock outcrop at an almost dried up brooklet, ca 1000 m a.s.l., 20 Aug 1972, I. Kukkonen (H 1654708; FIr 7978, as B. maritimus, depicted on, Fig. 3); Rezaiyeh to Mahabad $35 \mathrm{~km}$ northwest of Mahabad, saline flats, ca 1280 m a.s.l., 15 Jun 1971, J. Lamond, K. H. Rechinger, Iter Orientale $1971 \quad(\mathrm{H}$ 1205514; FIr 4191, as B. maritimus); in limosis $35 \mathrm{~km}$ northwest of Mahabad, 16 Jun 1971, K. H. Rechinger (W 8888; FIr 42175, as B. maritimus). Kordestan: Marivan, Lake Zarivar, 6 Jul 1971, Termeh (32500 IRAN), 29 May 2006, Amini Rad (IRAN 43965); 45-50 km from Sanandaj to Tangi-Sar village, $1300 \mathrm{~m}$ a.s.l., 31 May 2006, Amini Rad (IRAN 43964). Hamadan: Kuh Alvand, 7 Jun 1965, Babaii (IRAN 29415, W 522; FIr 66570-E, as B. maritimus). Kermanshah: Zardeh, Ghaleh, Yazdeguerd, 28 Jul 1967, Iranshahr and Termeh (IRAN 43971); Gahvareh, $1530 \mathrm{~m}$ a.s.l., 29 Jun 1998, Assadi (TARI 78757); southwest of Kermanshah, Seimare, 14 May 1904, Th. Strauss (JE).

Lorestan: Burujird [Brojerd], in marsh, 13 Jun 1941, Walter N. Koelz (W 586; FIr Borujerd, 18222, 18223, as B. maritimus); Doroud, in meadow, $5500 \mathrm{ft}$ a.s.l., 20 May 1940, Walter Koelz (W 1259; FIr Dow Rud, 15542, as B. maritimus); $50 \mathrm{~km}$ of Khorramabad, $1100 \mathrm{~m}$ a.s.l., 29 May 1937, M. Koeie (B; FIr Bisheh, 922, as B. maritimus). Bakhtiari: Seghahan, along stream; 25 May 1940, W. Koelz (W 1242; FIr 15011, as B. maritimus). Fars: between Shiraz and Zarghan, 29 May 1968, Sharafeh (IRAN 32437), 26 May 1968, Esfandiari (W 9483); between Zarghan and Marvdasht, 26 May 1968, Esfandiari 
(IRAN 30701; FIr 131150-E, as B. maritimus); ca $30 \mathrm{~km}$ S. Jahrom, $800 \mathrm{~m}$ a.s.l., 28 Nov 1987, Assadi and Akhani (TARI 61853); Tang-e Chogan-e Olia, Gav Shapour cave, in river side, 11 Jun 1973, Jiří Soják (BRA; FIr, as B. maritimus); $10 \mathrm{~km}$ west of Shiraz, 8 Jun 1973, Jiř́i Soják (BRA; FIr, as B. maritimus). Hormozgan: Minab, Tiab, 22 Apr 2003, Amini Rad and Tehrani (IRAN 35546, rev. by I. Kukkonen as B. glaucus, H 1723932); Biaban, Sirik, Sikoui, 7 Mar 1940, Behboudi (IRAN 32499); between Minab and Gourband, 5 Apr 1949, Behboudi (IRAN 17248, W 1352; FIr 347-E, as B. maritimus). Boushehr: $38 \mathrm{~km}$ of Boushehr, $28 \mathrm{~m}$ a.s.l., s. d., Farhand (TARI 15); Boushehr, Apr 1885, Stapf (WU; FIr 1727, as B. maritimus); $12 \mathrm{~km}$ southwest of Boushehr, Bahmani, 13 Mar 1937, M. Koeie (B). Khuzestan: Shoush, Shawor, 9 Nov 2005, Amini Rad and Torabi (IRAN 43967); between Ahvaz and Bandar-Mahshahr, $20 \mathrm{~km}$ of Mahshahr, $100 \mathrm{~m}$ a.s.l., 1 Jun 1991, Delghandi, Abbasi and Tehrani (IRAN 32502); $40 \mathrm{~km}$ of Mahshahr to Hendijan, $17 \mathrm{Apr}$ 2002, Tehrani and Eskandari (IRAN 37215); Shoush, 26 Oct 2004, Amini Rad and Eskandari (IRAN 43970); ca $25 \mathrm{~km}$ of Ahvaz to Bandare-Emam, $20 \mathrm{~m}$ a.s.l., $13 \mathrm{Apr}$ 1985, Mozaffarian (TARI 53500); Shoushtar, 13 Apr 1977, Jiř́ Soják (BRA); Khairabad River, $20 \mathrm{~km}$ east of Behbahan, boulder flood-plain, $400 \mathrm{~m}$ a.s.l., 30 Jun 1964, Martin L. Grant (W 17319; FIr 15899, as B. maritimus); Susan, Aug 1868, Haussknecht (JE). Kerman: Jiroft, Jaz Morian, Khanu, ca $400 \mathrm{~m}$ a.s.l., April 1950, F. Starmuehlner (W 638). Baluchestan: $18 \mathrm{~km}$ of Chabahar to Rask, 29 Apr 2005, Amini Rad and Torabi (IRAN 43966); Chabahar to Iranshahr, between Chabahar and Nasir-abad, 25-750 m a.s.l., 19 Nov 1976, Ershad et al. (IRAN 43969); 10-20 km of Beris to Chabahar, 27 Apr 2008, Amini Rad et al. (IRAN 49857); 5-10 km of Nobandian to Rask, 28 Apr 2008, Amini Rad et al. (IRAN 49858); between Zarabad and Chabahar, 26 Apr 2008, Amini Rad et al. (IRAN 49859); Zabol, Kianabad pasture, Lake Hamoun, 2 May 2008, Amini Rad et al. (IRAN 49860); Zabol, Ghorghori, Hamoun, 480 m a.s.l., 25 May 1984, Mozaffarian (TARI 63454); $115 \mathrm{~km}$ of Iranshahr to Chabahar, 750 m a.s.l., 7 Mar 1977, Runemark et al. (TARI 22359); Jazemorian Hamoun, 350 m a.s.l., Aug 1982, Babakhanlou (TARI 39998); Sistan, Ayazi (IRAN 43968; FIr 5862, as B. maritimus); ca $10 \mathrm{~km}$ east of Sarbaz, 1 Jun 1973, Jiř́ Soják (BRA; FIr 995, 997, as B. maritimus). Khorasan: Between Mashhad and Chenaran, alt. ca $1100 \mathrm{~m}$ a.s.l., 2 Jun 1948, K. H. and F. Rechinger, K. H. Rechinger Iter Iranicum II, 1948, Plantae P. Aellen Collaborante lectae (M 80472, W 5894; FIr 4673, as B. maritimus); $59 \mathrm{~km}$ west of Mashhad, swamp in semidesert, $1300 \mathrm{~m}$ a.s.l., 10 Jul 1964, J. S. Andersen and Ivar C. Petersen (W 21637; FIr 356, as B. maritimus); Bojnourd, Torbat, 8 Jul 1950, Manouchehri (W 6801; FIr 6066, as B. maritimus); west of Chenaran village ca $60 \mathrm{~km}$ west of Mashad, waste land between wheat field and highway, irrigation ditch, $1200 \mathrm{~m}$ a.s.l., 1 Aug 1972, I. Kukkonen (H 1700902, H 1654705 , H 1654358; FIr 7626, as B. maritimus). Tehran: Roudhen, 2-3 km from Mehrabad to Zaridar, 1650-1700 m a.s.l., 8 Jul 2007, Amini Rad (IRAN 47727); Qazvin, 8 Jul 1974, Mazaheri (IRAN 47598); Karaj, 1400 m a.s.l., 6 Jun 1936, D. E. Gauba (B; FIr 1581, as B. maritimus); Damavand: Pole Jajroud, 28 Apr 1909, Bruns (B).
Bolboschoenus maritimus (L.) Palla in Hallier and Brand (1905, p. 2532) (Fig. 5)

Basionym: Scirpus maritimus L. (1753, p. 51). Type "Habitat in Europae litoribus maritimis". Lectotype designated by Smith and Kukkonen (1999): Herb. Celsius 2: 212 (UPS). Epitype designated by Smith and Kukkonen (1999): [Sweden] E. Uppland, Roslagen, par. Börstil, 2 km west of Kallö, near Husbacka, 14 Oct 1995, Nilsson 9515 (UPS; isoepitype: PR!).

Taxonomic synonym: Scirpus compactus Hoffm. (1800, p. 25).

Based on the same type: Scirpus maritimus f. compactus (Hoffm.) Nilsson (1901, p. 673). - Bolboschoenus maritimus subsp. compactus (Hoffm.) Hejný (1950, p. 1844). B. maritimus var. compactus (Hoffm.) T. V. Egorova in Tolm. (1976, p. 18).

Type [Germany]. Lectotype designated by Tatanov (2005): Krocker 1796, Fl. Silesiaca, Tab. 15. Epitype designated by Tatanov (2007): Militsch [Milicz], Ausstiche am Bahnhofe, Jun [18]89, Callier s.n., A. Callier, Flora Silesiaca Exsiccata no. 106 (LE!).

Perennial plants, (20-) 35-70 (-100) cm tall. Rhizome creeping, 2.0-3.5 $(-5) \mathrm{mm}$ in diameter, reddish brown to black, bearing spherical or ellipsoid tubers $0.5-2.0 \mathrm{~cm}$ in diameter. Stem sharply trigonous, (1.0-) $1.5-2.0 \mathrm{~mm}$ in diameter, grey-green to light green, nodded with elongated internodes, sides flat or slightly depressed, edges smooth or scabrous towards the top. Leaves shorter to longer than stem; sheaths (4.5-) 6.0-10.0 cm long; leaf blades (2-) 3-4 (-6) $\mathrm{mm}$ wide, flat, keeled, green to grey-green, margins smooth or slightly scabrous towards the top. Inflorescence head-like, constituted of a fascicle of (3-) 4-8 sessile spikelets, or compound, formed of a fascicle of sessile spikelets and 1 or 2 rays bearing $1-3$ spikelets; involucral bracts $2-3$, to $20 \mathrm{~cm}$ long. Spikelets 10-25 mm long, 4-8 $\mathrm{mm}$ wide, ovate or ellipsoid, obtuse, yellow-brown, light brown to brown; glume like bract 5-6 mm long, with arista to $2 \mathrm{~mm}$; glume like prophyll ca $4 \mathrm{~mm}$; floral scales $7 \times 3 \mathrm{~mm}$, cymbiform, light brown, rusty brown to brown, arista $1-2 \mathrm{~mm}$ long, frequently curved, margins scarious and nerveless, ciliate, apex truncate and trifid; perianth bristles 4, caducous, unequal, shorter than achene (to $1 / 2$ or $2 / 3$ of achene length); anthers 3-4 mm long; styles trifid, but flowers with bifid styles may also be present in the same inflorescence. Achenes 3.0-3.5 × 1.8-2.4 mm, obovate, plano-convex, biconvex to subtrigonous, rusty-brown to dark brown, edges round, beak to $0.2 \mathrm{~mm}$, surface with conspicuous polygonal network structure (anticlinal cell walls depressed), surface cell walls in fully ripe achenes not translucent; pericarp in cross-section formed of a thick exocarp consisting of one layer of cylindrical cells radially elongated and filled by air, and a thin sclerenchymatic mesocarp and endocarp; exocarp approximately twice as thick as mesocarp (ratio of exocarp: mesocarp ca $2: 1$ ).

\section{Distribution and ecology}

Bolboschoenus maritimus inhabits lake edges, wet places around roads and grasslands along streams; habitats are 

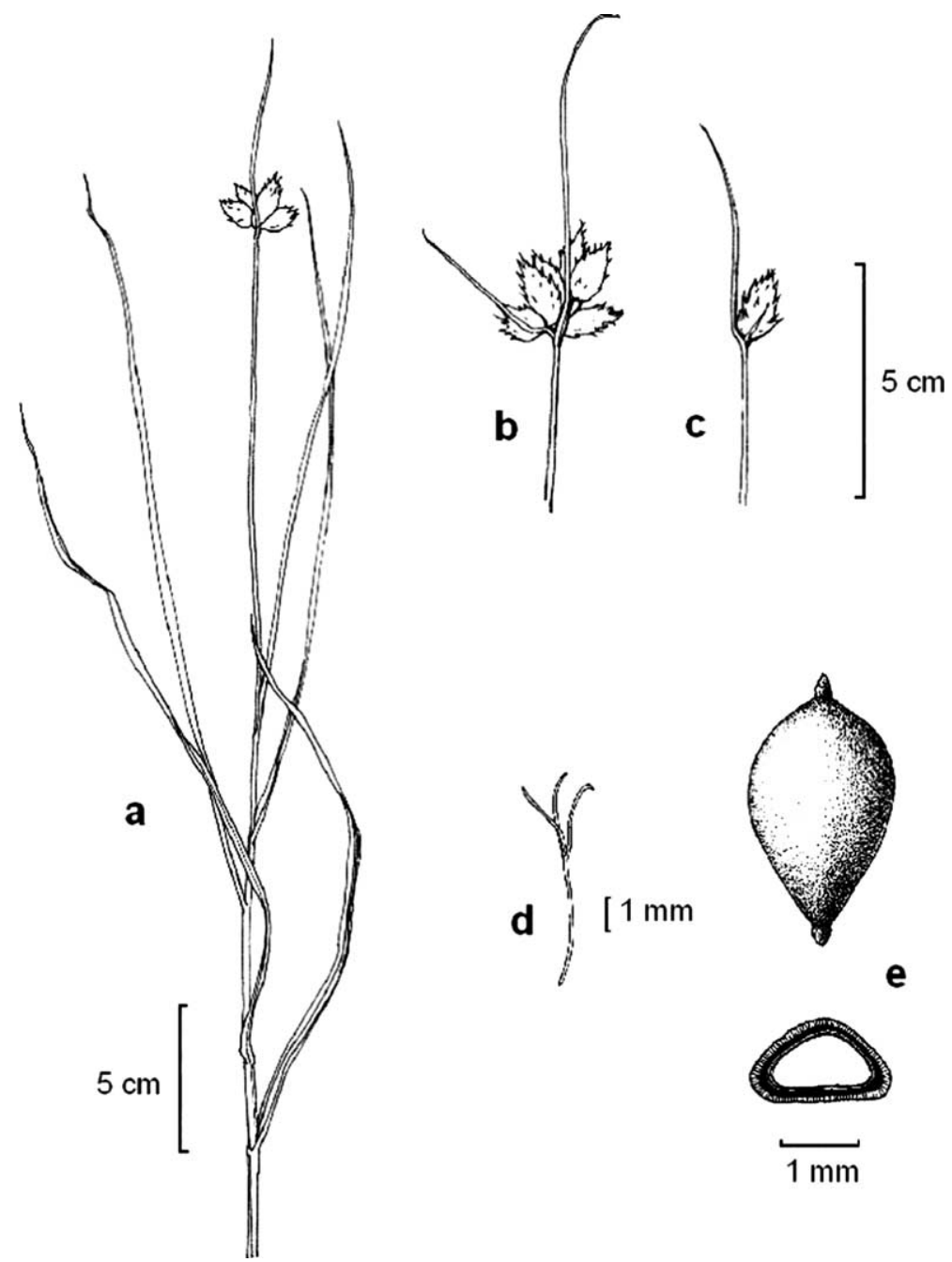

Figure 5. Bolboschoenus maritimus. (a) flowering plant, (b)-(c) inflorescence, (d) trifid style, (e) achene (dorsal view and cross-section, with the sclerenchymatic mesocarp in black). Drawn from a cultivated plant from Fars, Quadar Abad, voucher specimen in PRA. Del. Z. Hroudová.

frequently saline (muddy brackish places, the shore of salt lakes), and mostly at high altitudes (1130 to $2070 \mathrm{~m}$ a.s.l.). The centre of the distribution area is in Europe. The halophyte characteristic of this species determines its occurrence; it is widely distributed along the coasts of Europe, in the British Isles and Sardinia, and also in inland saline regions (Hroudová et al. 2007a). To the north, it reaches the Murmansk Region in southern Kola Peninsula in Russia (Tatanov 2004, 2007). In the south, the distribution continues along the coast of the Mediterranean Sea (southern Europe to Algeria and Morocco) to the Black Sea and Turkey, to Iraq and Iran. The eastern border of the distribution area of $B$. maritimus is not known in detail; it occurs through the European part of Russia (Egorova 1976) to the Ural Mountains, Kazakhstan and Kyrgyzstan, and in an isolated area in Siberia, in the surroundings of the town of Barnaul (Tatanov 2004). An isolated area of distribution is in South Africa (Browning and Gordon-Gray 1993). In Iran, B. maritimus reaches the southeastern border of its distribution and is rare; it is concentrated to Azerbaijan, and some single localities are found in Fars and in central Iran
(Tehran, Semnan and Arak Provinces), in the IranoTuranian region (Fig. 6).

\section{Notes}

Bolboschoenus maritimus is variable with respect to the morphology of the inflorescences (in addition to a fascicle of sessile spikelets, also some rays bearing spikelets can be found), as well as in fruit shape (achenes slightly convex on abaxial side to subtrigonous). Further, the style (predominantly trifid) may be bifid in some flowers. To distinguish B. maritimus from $B$. affinis, the colour of the floral scales can be used (yellowish-white to light brown in B. affinis, mostly rusty brown in $B$. maritimus), and as an additional character, the translucency of the outer cell walls on the achene surface can be used as they are never translucent in ripe fruits of B. maritimus (Kukkonen 1998). However, only fully ripe fruits should be used for determination, as translucent cell walls may be observed in unripe fruits of B. maritimus. Nevertheless, the description of the inflorescence in 'Flora Iranica' (Kukkonen 1998) “a multiple spike, sometimes an anthelodium to $100 \mathrm{~mm}$ in diameter, less 


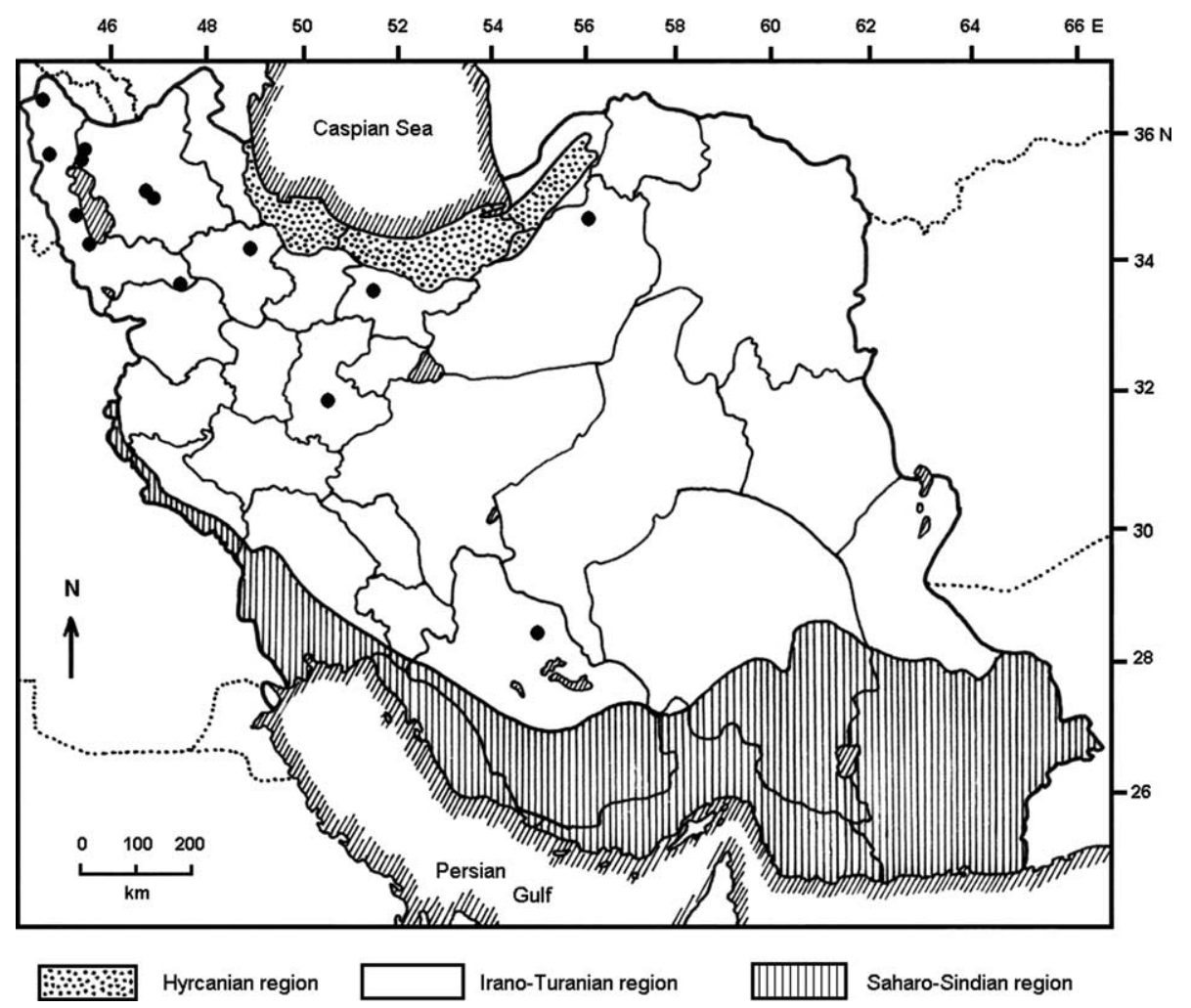

Figure 6. The distribution of Bolboschoenus maritimus in Iran.

often a cluster of sessile spikes; primary branches to $50 \mathrm{~mm}$, each with a cluster of 1-7 sessile spikes" includes a very wide range of variation, from which large anthelodium corresponds better to B. glaucus. In the description of other distinguishing characters, a technical error occurred in 'Flora Iranica': in fruit description one line was dropped during pagemaking; the correct text should be: "stigmas predominantly 3 , frequently 2 , often mixed in a single spike. Nut 2.3-3.2 $\times 1.9-2.2 \mathrm{~mm}$, trigonous, plano-convex, apex mostly conical, wall hard, dark brown or white, glossy, outer wall of epidermal cells not translucent" (Pertti Uotila in litt.). The characters "apex mostly conical" and "wall hard, glossy" correspond again to B. glaucus, and the given fruit size of $B$. maritimus is overlapping to considerable extent with that of B. glaucus. As appeared by the revision of herbarium material collected by I. Kukkonen, the plant used for the drawing of $B$. maritimus for Flora Iranica (Kukkonen 1998; Table 1, Fig. 3) was B. glaucus. It has fruit of smaller size, convex on dorsal side, conical apex, some short perianth bristles persistent; the inflorescence structure with narrow 'catkin-like' spikelets also corresponds to B. glaucus. Several other specimens referred to in 'Flora Iranica' as to B. maritimus appeared to belong to B. glaucus (see list of specimens of B. glaucus). On the other hand, the plant used for drawing B. affinis for 'Flora Iranica' (Kukkonen 1998; Table 1, Fig. 2) does not correspond to $B$. affinis in rusty brown colour of spikelets, in number of stigmas (it has trifid style), and in achenes highly convex to subtrigonous with slightly marked edge on dorsal side. The achenes have thick exocarp, but also well developed mesocarp, which together with achene shape might indicate possible hybridization with $B$. glaucus. Despite of the intermediate characters, the plant is closest to $B$. maritimus.

\section{Specimens examined}

Azerbaijan: $16 \mathrm{~km}$ of Marand to Jolfa, $1325 \mathrm{~m}$ a.s.l., 22 Jun 2009, Amini Rad (IRAN 53893); Makou to Buralan, $1380 \mathrm{~m}$ a.s.l., 21 Aug 2007, Amini Rad and Pahlevani (IRAN 48931); $28 \mathrm{~km}$ of Khoy to Ghotour, $1470 \mathrm{~m}$ a.s.l., 20 Aug 2007, Amini Rad and Pahlevani (IRAN 48868); $70 \mathrm{~km}$ of Mahabad to Oroumyeh, around road, $1300 \mathrm{~m}$ a.s.l., 17 July 1997, Sangari and Tehrani (IRAN 43963); Takab, Takht-e Soleyman, AhmadAbad-Sofla, 17 Jul 2006, Eskandari et al. (IRAN 47599) [intermediate plant, fruit shape as in B. glaucus, but thicker exocarp]; $5 \mathrm{~km}$ of Tasuj to Salmas, $1130 \mathrm{~m}$ a.s.l., $25 \mathrm{Jul}$ 1990, Taheri and Izadpanah (TARI 68162); Bostan abad, Ghorigol lake margin, 1950 m a.s.l., 22 Jul 1990, Assadi et al. (TARI 68455); $60 \mathrm{~km}$ of Oroumyeh toward Mahabad, Heydar-Abad, 18 Jun 1999, Termeh and Sangari (IRAN 47724); ca $10 \mathrm{~km}$ northwest of Zanjan, in pratis prope rivulum, 5 Jul 1973, Jiř́ Soják (BRA; FIr 7478, as B. affinis); Lake Oroumyeh: west side, sandy/gravelly soil on shore of salt lake, in muddy brackish places, $1300 \mathrm{~m}$ a.s.l., 14 Jun 1963, M. Jacobs (W 4520; FIr 6891, as B. maritimus); ca $85 \mathrm{~km}$ west of Miyaneh on the road from Zanjan to Tabriz, irrigation ditch, Onobrychis viciifolia field, $1800 \mathrm{~m}$ a.s.l., 19 Aug 1972, I. Kukkonen (H 1674700; FIr 7960, as B. affinis, depicted on Fig. 2) [Plant with three stigmas, fruits convex to subtrigonous on dorsal side, with thick exocarp, but also well developed mesocarp; closest to $B$. maritimus, not $B$. affinis]. 
Fars: Quadar Abad, $8 \mathrm{~km}$ south of the bridge, $2070 \mathrm{~m}$ a.s.l., 1997, J. Sádlo (IRAN 32501, PRA). Arak: S Kavire Mighan, ca $2 \mathrm{~km}$ north of Emamzadeh Khaton, Namak lake margin, 31 Jul 1986, Akhani (TARI 972). Semnan: Touran protected area, Baghestan, $1220 \mathrm{~m}$ a.s.l., $14 \mathrm{Jul}$ 1976, Freitag (TARI 13672). Tehran: Mardabad, $1250 \mathrm{~m}$ a.s.l., 4 Oct 1938, D. E. Gauba (B).

\section{Bolboschoenus planiculmis (F. Schmidt) T. V. Egorova (1967, p. 20) (Fig. 7)}

Basionym: Scirpus planiculmis F. Schmidt (1868, p. 190). Type: "Ssussuja-Mündung". Lectotype designated by Egorova and Tatanov (2003): Ssussuja Mündung auf schlammigen Boden, 10 Aug 1861, F. Schmidt s. n. (LE!). Epitype designated by Egorova and Tatanov (2003): Yuzhnyi Sakhalin, Anivskii zaliv, kolo sel. Sinba (Dachnoe), primorskie plavni, 12 Sep 1948, M. G. Popov s. n. (LE!).

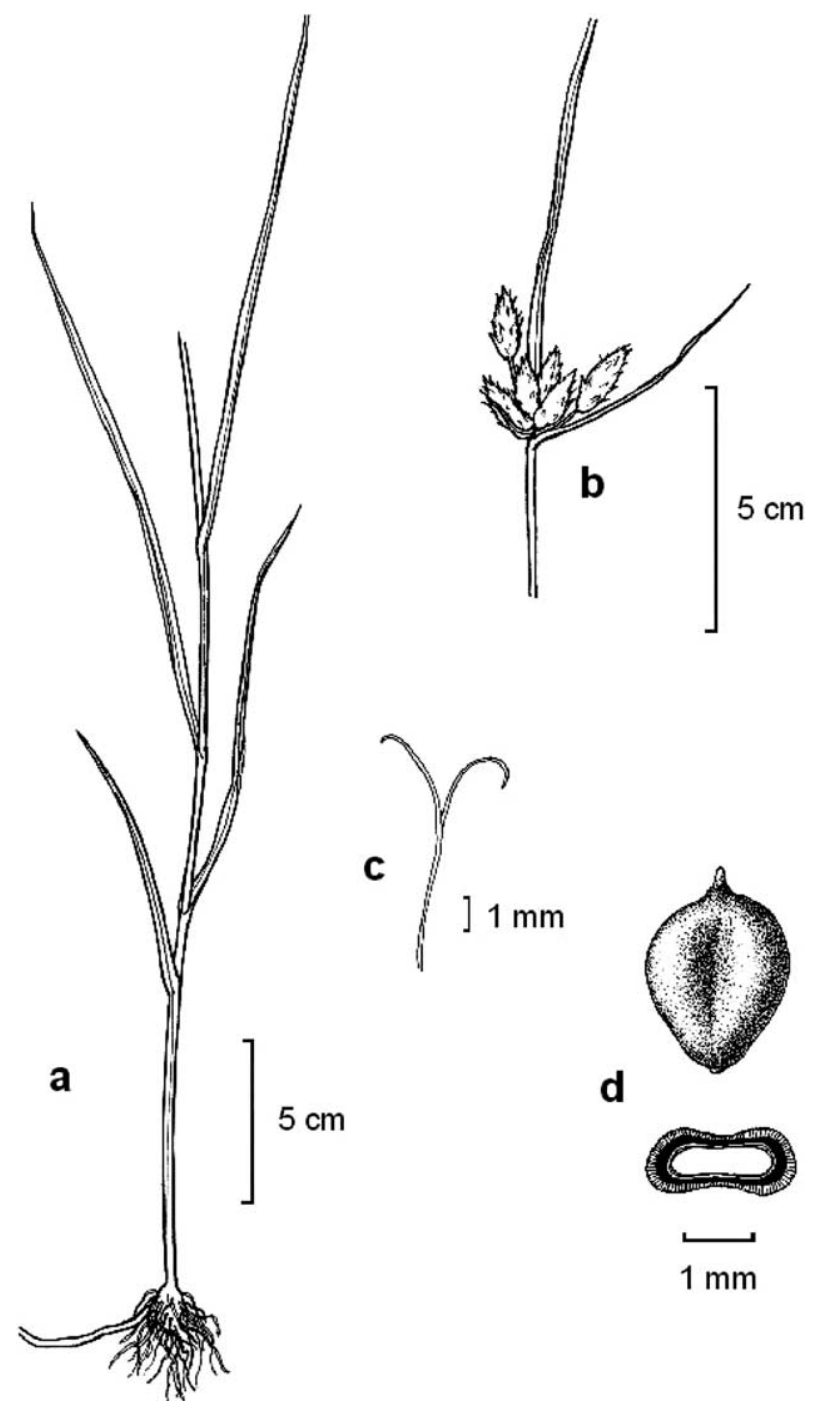

Figure 7. Bolboschoenus planiculmis. (a) the lower part of a stem with tuber, (b) inflorescence, (c) bifid style, (d) achene (dorsal view and cross-section, with the sclerenchymatic mesocarp in black). Drawn from a voucher specimen from Tehran, Pardisan Park, IRAN 47725. Del. Z. Hroudová.
Taxonomic synonyms: Scirpus koshewnikowii Litv. ex Kots (1882, p. 220).

Based on the same type: B. koshewnikowii (Litv. ex Kots) A. E. Kozhevn. (1988, p. 189).

Type: 'Oblast' Voiska Donskago bliz stanitsy Uryupinskoi". Neotype designated by Egorova and Tatanov (2003): Novotcherkassk, ad ripam fluvii Axaj, 9 Jun 1911, A. Jakuschev s. n. (LE!).

- Scirpus compactus var. orientalis Litv. (1919, p. 204, no. 2792).

Type: "Prov. Transbajcalia, distr. Nerczinsk, ad ripas salsuginosus lac. Suchoj-Bajgul.” Lectotype designated by Egorova and Tatanov (2003): [Russia] Prov. Transbajcalia, distr. Nerczinsk, ad ripas salsuginosus lac. Suchoj-Bajgul, Aug 1911, V. Sukachev and G. Poplavskaya, Herbarium Flora Rossicae no. 2792 (LE!).

- S. biconcavus Ohwi (1944, p. 109-110).

Type. "Yezo: Nemuro". Holotype: Nishiwada, prope Nemuro, Yeso, 10-11 Sep 1931, J. Ohwi s. n. (KYO!).

Perennial plant, (30-) $40-70 \mathrm{~cm}$ tall. Rhizome creeping, $2.2-3.0 \mathrm{~mm}$ in diameter, reddish brown, bearing spherical or elongated tubers to $15 \mathrm{~mm}$ in diameter. Stem trigonous to sharply trigonous, sides flat or slightly depressed, (1.3-) $1.5-2.0 \mathrm{~mm}$ in diameter, grey-green or green, smooth to scabrous towards the top, nodded with elongated internodes. Leaves as long or longer than stem; sheaths (2.5-) $4.0-10.0 \mathrm{~cm}$ long, yellow-brown or grey-green to dark brown; blades (2.0-) $3.0-4.5 \mathrm{~mm}$ wide, flat or folded, keeled, grey-green or green, smooth, slightly scabrous towards the top. Inflorescence head-like, consisting of 1-3 (-4) sessile spikelets, or composed of a central group of 3-7 $(-11)$ sessile spikelets and 1-2 (-4) branches bearing 1 or 2 spikelets; involucral bracts (2-) $3-13 \mathrm{~cm}$ long. Spikelets (11-) 13-20 mm long and 5-8 $\mathrm{mm}$ wide, ovate, obtuse, light brown to brown; glume-like bract to $8 \mathrm{~mm}$ long, with arista to $2.5 \mathrm{~mm}$ long; glume-like prophyll to $5 \mathrm{~mm}$ long; floral scales 7-9 $\mathrm{mm}$ long and 3-4 mm wide, cymbiform, yellow-brown or rusty brown, with arista to $1.5(-2) \mathrm{mm}$, margins scarious and nerveless, ciliate, smooth or short barbed, apex truncate and slightly trifid; perianth bristles 4-5, caducous, mostly shorter than achene; anthers 2.5-4 mm long; styles bifid (rarely, flowers with trifid styles also present in the same inflorescence). Achenes 2.5-3.3 mm long and 1.9-2.2 mm wide, obovate, biconcave or flat-concave (concave on abaxial side), grey-brown or ochre to rusty brown, edges rounded, beak to $0.3(-0.5)$ $\mathrm{mm}$, surface with a striking polygonal network (cell wall outlines depressed); pericarp in cross-section with well developed exocarp formed by one layer of cylindrical cells radially elongated and filled by air, sclerenchymatic mesocarp and thin sclerenchymatic endocarp; exocarp layer approx. of the same thickness as mesocarp, thicker over rounded angles than on concave faces.

\section{Distribution and ecology}

Bolboschoenus planiculmis occurs in temporarily flooded wet depressions and in irrigated fields. It was found in Iran only in secondary habitats - wet places in village, in city parks and on arable land. Bolboschoenus planiculmis 
is a plant with a continental distribution through Eurasia; its area extends from central Europe through eastern Europe, central Asia and Siberia (approx. within $40^{\circ}$ and $\left.60^{\circ} \mathrm{N}\right)$ to the Russian Far East and Sakhalin Island, where it reaches to the sea coast, and further to China and Japan (Egorova 1967, 1976, Hayasaka and Ohashi 2002, Egorova and Tatanov 2003, Hroudová et al. 2007a). Some localities are known in southern Europe (Bulgaria, Croatia, Italy). Bolboschoenus planiculmis is very rare in Iran (Fig. 8). It has been found so far in three localities in the Hyrcanian and Irano-Turanian regions, in habitats strongly influenced by human activities, which indicates an adventive origin. It might be introduced as a weed in rice fields. Its further spread to new suitable habitats is not excluded.

\section{Notes}

In $B$. planiculmis, the outer cell walls of the achene exocarp may also be translucent, but never with a visible white network of cell walls (cell walls are brownish coloured).

\section{Specimens examined}

Gilan: Langerud, Chamkhaleh, Hassanbekandeh village, 22 Jun 2004, Amini Rad (IRAN 7227, rev. by I. Kukkonen as B. affinis); Rasht, 10 Jun 1985, R. Moussavi (IRAN 34463); Rasht, Rice Research Station, 31 Jul 2002, Amini Rad and Tehrani (IRAN 38640, H 1717179). Tehran: Pardisan Park, 24 Jun 2007, Amini Rad (IRAN 47725).
Bolboschoenus schmidii (Raymond) Holub (1973, p. 186) (Fig. 9)

Basionym: Scirpus schmidii Raymond in Koeie and Rech. f. (1965, p. 15).

Type: "Persia: Khorasan: Bar, 1780-2350 m”. Holotype: Persia: Khorasan: Bar, 1780-2350 m a.s.l., s. a., Schmid 6288 (G 00074197, isotype: W!).

Perennial plant, (30-) 50-60(-80) cm long. Rhizome creeping, $2.0-3.5 \mathrm{~mm}$ in diameter, covered by reddishbrown scales, bearing small spherical to ellipsoid tubers $0.5-1.0 \mathrm{~cm}$ in diameter. Stem sharply trigonous, (1.3-) $1.5-2.0 \mathrm{~mm}$ in diameter, grey-green, smooth to scabrous towards the top, nodded. Upper leafless part of the stem may take $1 / 3-2 / 3$ of total stem length, in extreme cases stem internodes are shortened and all leaves are 'basal', attached to stem base. Leaves shorter or longer than stem, depending on habitat conditions; sheaths $(3.5-) 7.0-8.0 \mathrm{~cm}$ long, grey-green or yellow-brown to brown, margins of scarious side straight; blades 3.0-5.5 (-6.0) mm wide, flat or folded, keeled, grey-green or green, margins smooth or scabrous towards apex. Inflorescence head-like formed of one fascicle of 4-6 sessile spikelets, sometimes also with 1 or 2 branches bearing 1 (rarely 2 ) spikelets; bracts $1-2$ to $11 \mathrm{~cm}$ long. Spikelets 6-12 mm long and 5.0-7.0 (-8.5) $\mathrm{mm}$ wide, approx. spherical to widely ovate or sometimes ellipsoid, brown, yellow-brown to white-yellowish; glumelike bract to $6-7 \mathrm{~mm}$ long, arista to $3 \mathrm{~mm}$ long; glume-like prophyll to $4-5 \mathrm{~mm}$ long; floral scales $5.0-7.5 \mathrm{~mm}$ long and $3-4 \mathrm{~mm}$ wide, arista to $1.5 \mathrm{~mm}$ long, slightly curved, cymbiform, pale yellow to yellow-brown, margins scarious

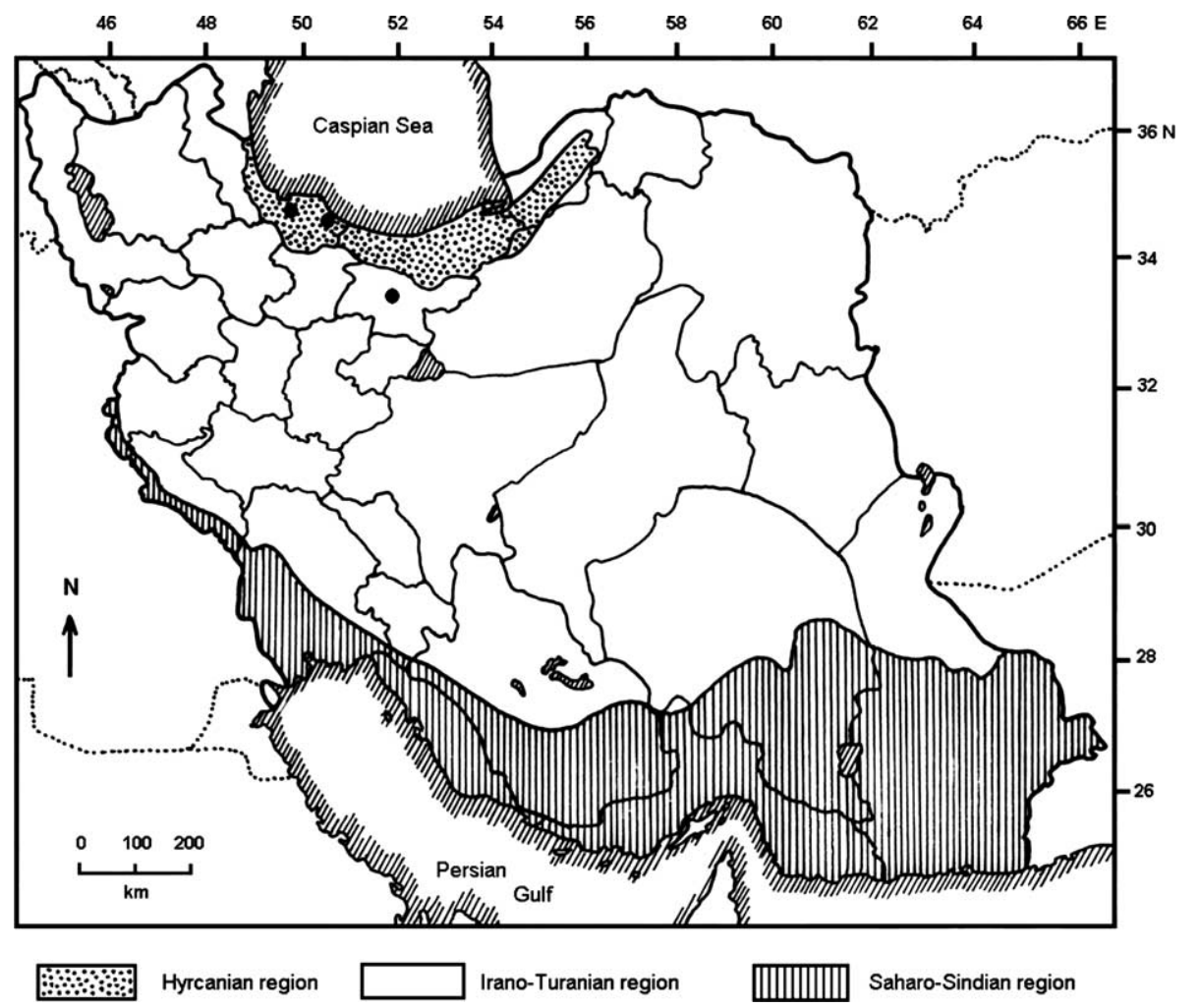

Figure 8. The distribution of Bolboschoenus planiculmis in Iran. 

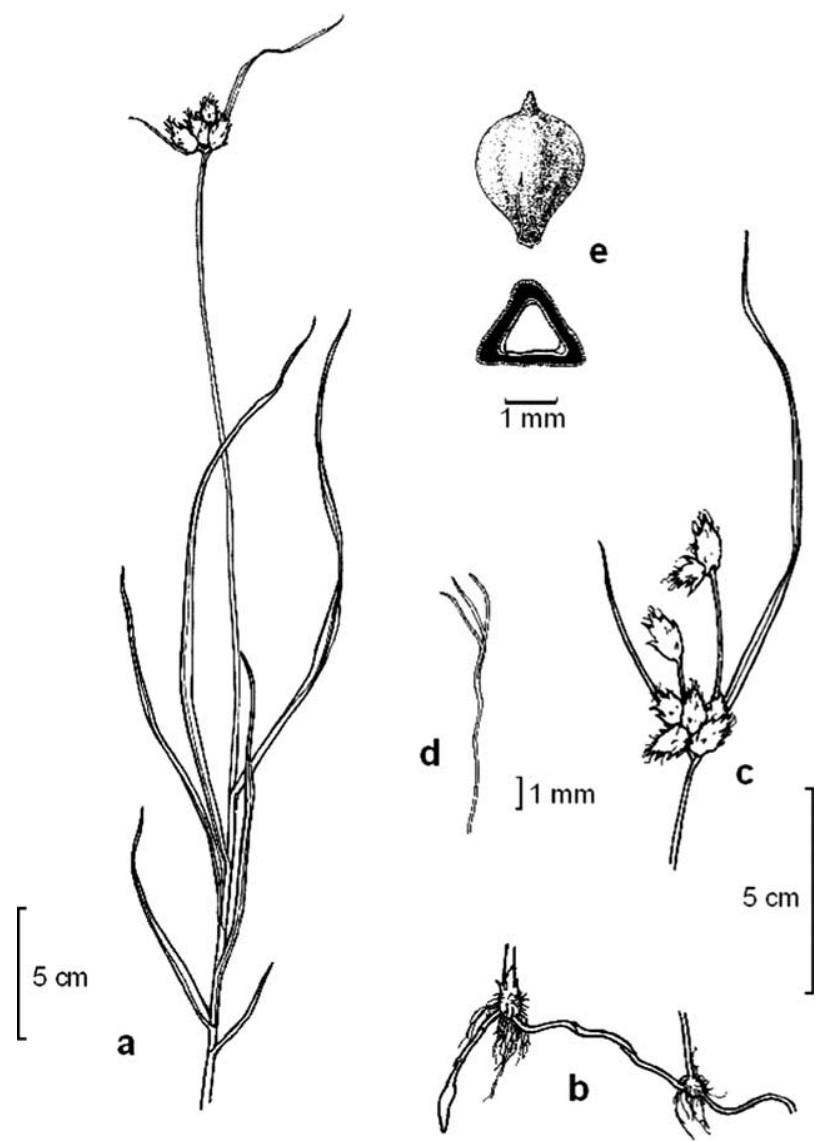

Figure 9. Bolboschoenus schmidii. (a) flowering plant, (b) rhizome with underground tubers, (c) inflorescence with sessile spikelets and rays, (d) trifid style, (e) achene (dorsal view and cross-section, with the sclerenchymatic mesocarp in black). Drawn from voucher specimens from Semnan, Biarjomand, Kuh-e Majerad, Kalat Asbe, IRAN 47731/2 (a), IRAN sine no. (b), Khorasan, Neyshabour, Bar, IRAN 47728/1 (c, d, e). Del. Z. Hroudová.

and nerveless, ciliate, sparsely barbed, apex truncate and trifid; perianth bristles $4-6$, partly caducous, reaching $1 / 3$ to $1 / 2$ of achene length; anthers $4 \mathrm{~mm}$ long; styles trifid, but rarely some flowers with bifid styles also present in the same inflorescence. Achenes 3.0-3.9 mm long and 1.9$2.5 \mathrm{~mm}$ wide, obovate, with beak to $0.2 \mathrm{~mm}$ long, trigonous, yellow-brown to dark brown, surface with a striking polygonal network; pericarp formed of thin exocarp, well developed thick sclerenchymatic mesocarp and thin sclerenchymatic endocarp.

\section{Distribution and ecology}

Bolboschoenus schmidii inhabits habitats along streams or water sources, in channels, and near villages. It was described from Iran (Prov. Khorasan, see above) and the distribution area is concentrated to southwestern and central Asia: Iran, Afghanistan, Kazakhstan, Uzbekistan and Turkmenistan (Tatanov 2003a). The detailed distribution in Iran is currently poorly known. The localities of this species are sparsely distributed, especially in northern and northeastern Iran, at higher altitudes (950-2200 m a.s.l.); one locality is in the Kerman province near the centre of
Iran (Fig. 10). All of the known localities belong to the Irano-Turanian region.

\section{Notes}

Although the exocarp layer is thin, the polygonal network on the achene surface is usually easily visible. It is caused by the partly translucent outer cell walls and colourless walls of the exocarp cells, which enables one to see the anticlinal cell walls as a white network. Nevertheless, rarely also deep brown achenes without white network on the surface may be found, in their shape resembling those of B. medianus (Cook) Soják or B. laticarpus Marhold et al. (some achenes flattened to subtrigonous on dorsal side). The colour of floral scales (and thus of spikelets) may be variable: an isotype specimen in herbarium W possess white-yellowish spikelets, but in some other plants with inflorescence structure and fruit shape and anatomy typical of B. schmidii the spikelet colour was light brown to rusty brown. The character "leaf bases concentrated to the stem basis near each other" used by Tatanov (2003a) for distinguishing B. schmidii from B. maritimus, B. planiculmis and B. popovii probably represents an ecomorphosis, caused by habitat conditions, namely by drying of habitat. The plants of B. schmidii cultivated from seeds under satisfactory moisture and nutrient conditions were 40 to $60 \mathrm{~cm}$ tall, with upper leafless part taking $1 / 3$ to $1 / 2$ of the stem. Similar habit was observed also in some herbarium specimens collected in Iran from natural habitats; in some other specimens, however, proportion of upper leafless part was $1 / 2$ to $2 / 3$ of the stem, while other plants were very small, with the proportion of upper leafless part $1 / 4$ to $1 / 5$ of stem length (they resembled seedlings). We can conclude that the proportion of the upper leafless part of the stem is variable in B. schmidii and depends on habitat conditions. Besides, plants with 'basal' leaves may also occur in other species (B. maritimus, B. planiculmis, and B. glaucus).

\section{Specimens examined}

Hamadan: Shahnaz Dam, Yalfan (mts), 1980-2200 m a.s.l., 12 Jul 1974, Termeh and Moussavi (IRAN 30712; FIr 35131-E, as B. maritimus); S Zamanabad an der Strasse nach Jovkär, $1940 \mathrm{~m}$ a.s.l., Bachufer, 4 Sep 1977, K. P. Buttler and R. von Bothmer ( $\mathrm{H}$ 1153309; FIr Buttler 23040 and Bothmer, as B. affinis) [plant with some fruits rounded, subtrigonous, and with somewhat thicker exocarp, but it may fall into variation of $B$. schmidii.]. Kerman: $31 \mathrm{~km}$ of Ravar to Chatroud, 1850 m a.s.l., 1 Jun 1986, Assadi and Bazgosha (TARI 56324). Khorasan: Birjand, Zeyni, Giyouk (Dam), 2 Jun 2007, Eskandari and Torabi (IRAN 47726); between Mashhad and Chenaran, 2 Jun 1948, Rechinger et al. (IRAN 17246); Neyshabour, Bar, 1615-1650 m a.s.l., 29 Jun 2007, Amini Rad et al. (IRAN 47728). Semnan: Biarjomand, Touran protected area, Kuh-e Majerad, Kalat-Asbe, 950-970 m a.s.l., 12 Jun 2003, Mozaffarian (TARI 83663), 27 Jun 2007, Amini Rad et al. (IRAN 47731, 47729). Tehran: ca $75 \mathrm{~km}$ south of Tehran on the road to Qom, dry semidesert, surroundings of a small well, $1360 \mathrm{~m}$ a.s.l., 14 Aug 1972, I. Kukkonen (H 1654699; FIr 7882, as B. affinis); 5 km from Firouzkuh to Semnan, 1990 m a.s.l., 26 Jun 2007, Amini Rad et al. (IRAN 47730); Tehran, ca $20 \mathrm{~km}$ south of Damavand city, 


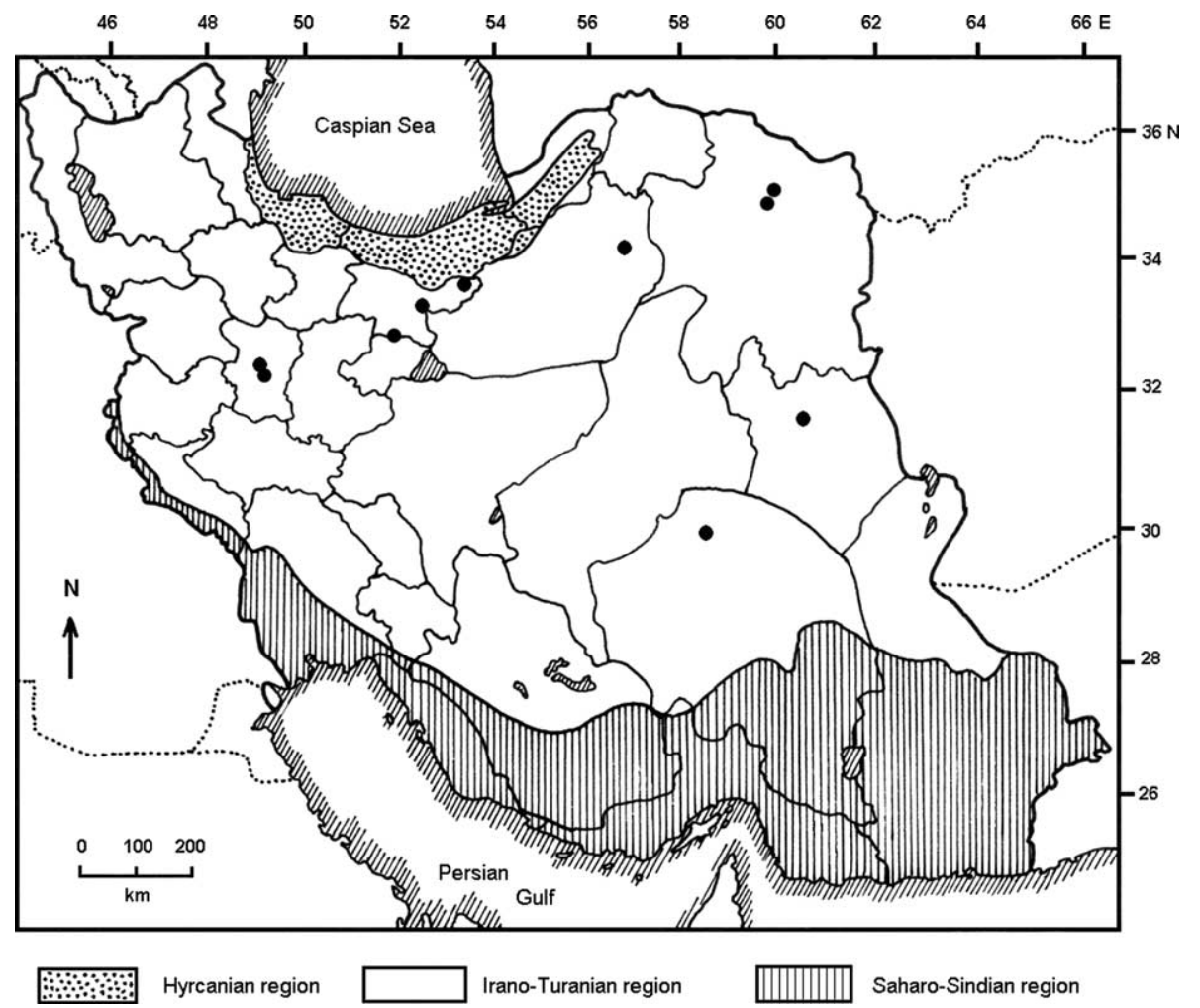

Figure 10. The distribution of Bolboschoenus schmidii in Iran.

between Tamisioun and Aselon, 1550-1650 m a.s.l., 22 Jun 1985, Mozaffarian (TARI 53923).

\section{Discussion}

In 'Flora Iranica', Kukkonen (1998) included B. schmidii (as Scirpus schmidii) as a synonym of $B$. affinis. In the list of revised specimens of $B$. affinis also the type specimen of Scirpus schmidii was given. Tatanov (2003a) drew attention to the differences between $B$. affinis and B. schmidii in the achene shape and pericarp anatomy, and regarded B. schmidii as a separate taxon. In agreement with the character values in studied plant material from Iran (trigonous achenes with a thin exocarp in B. schmidii, flattened to slightly biconvex achenes with a thick exocarp in $B$. affinis), we support the separation of $B$. schmidii from $B$. affinis. Kukkonen deemed the isotype specimen of B. schmidii in the herbarium collection in Vienna (W) to be $B$. affinis likely based on the yellow-whitish colour of its spikelets. Nevertheless, trigonous achenes with a thin exocarp clearly distinguish $B$. schmidii from $B$. affinis, and spikelet colour may vary in $B$. schmidii. Owing to the combination of characters typical for morphotypes in $B$. yagara and $B$. affinis (trigonous fruits with a thin exocarp, but mostly sessile spikelets of a whitish to brown colour), an ancient hybrid origin of this taxon cannot be excluded. This hypothesis might be confirmed or denied by molecular analyses.

On the other hand, in agreement with Kukkonen (1998) and contrary to Tatanov (2007), we include B. popovii as a synonym into $B$. affinis for the following reasons.
The distinguishing characters between $B$. affinis and B. popovii (as reported by Egorova 1967, 1976, Tatanov $2004,2005,2007)$ are very weak and their values are overlapping in Iranian plants. The distinguishing of both species is difficult, in many cases impossible. Owing to the fact that both $B$. affinis and B. popovii occur in Iran (Tatanov 2007), the origin of transitional types as a result of hybridization is not excluded. The original type specimen for the name Scirpus affinis was deposited in herbarium B (Berlin-Dahlem), but it was destroyed during the war. A new lectotype was chosen by I. Tatanov (original material collected by Roth deposited in LE) and he chose also a fertile plant as an epitype from eastern India, collected by Stocks (epitype: LE, isoepitypes: C, KW, P; Tatanov 2007).

Egorova (1967) described Bolboschoenus popovii from central Asia, distinguishing this species by the head-like inflorescence formed of sessile spikelets, with short, widely rounded spikelets of a yellow-whitish colour, and by widely ovate to oval, plano-convex fruits. No plant corresponding to the type specimen of $B$. popovii in all of these characters was found among the studied specimens from Iran. In Iranian plants, some plants with short spikelets in the head-like inflorescence and plano-convex fruits, but with light brown spikelets were found, as well as plants with yellow-whitish spikelets and slightly plano-convex fruits, but with elongated spikelets in a branched inflorescence with some rays, or plants with a head-like inflorescence with short spikelets, but light brown spikelets and flat to slightly plano-concave fruits. Among the specimens of a given morphotype, no plants with purple-striped floral scales were found (we have found purple colour on spikelets only in some plants belonging to B. glaucus). 
Bolboschoenus affinis was in the literature frequently classified as a subspecies of B. maritimus (Govaerts and Simpson 2007). The colour of the floral scales varies in some plants of $B$. affinis, showing in Iranian plants a transitional character to $B$. maritimus. The colour of the achenes varies as well (but frequently may depend on the ripeness of fruits, as does the translucency of cell walls). Nevertheless, the phylogenetic relationship of both species is not known, and possible hybridization resulting in intermediate plants cannot be excluded as well. Thus we accept the classification of both taxa at the species level.

Plants identical with European B. maritimus (Smith and Kukkonen 1999) were rarely found in Iran. Kukkonen (1998) reported widely conceived B. maritimus for the whole 'Flora Iranica' area. The description of $B$. maritimus in 'Flora Iranica' (cited above) does not fully correspond to the type specimen and to plants distributed in Europe, some characters correspond rather to $B$. glaucus; the drawing of B. maritimus represents B. glaucus. Although $B$. glaucus is included in 'Flora Iranica', it was not given directly for Iran. Checking specimens cited in 'Flora Iranica', we can see that most of those referred to as $B$. maritimus are now determined as $B$. glaucus, one as $B$. schmidii and only one as $B$. maritimus, from eight specimens originally referred to as $B$. affinis three are now determined as $B$. affinis, three as B. schmidii (including type specimen) and two as $B$. maritimus. It is evident, that not only $B$. schmidii but also B. glaucus were not properly distinguished in 'Flora Iranica'. Bolboschoenus glaucus appears now to be the most frequent Bolboschoenus species in Iran. On the contrary, B. maritimus appears to be sparsely distributed. In 'Flora of Pakistan', Kukkonen (2001), using characters in the fruit anatomy, did not report B. maritimus for Pakistan. The localities of $B$. maritimus in Iran may thus represent the southeastern border of its continuous distribution southwards in Asia.

We can conclude that considerable morphological variation in the inflorescence structure, spikelet colour and achene shape can be observed in Iranian plants within the group of $B$. affinis/popovii and B. maritimus. It is difficult to decide whether some intermediate plants fall into the variation of individual species or whether putative hybrids can be expected between species with overlapping distributions. Cultivation experiments together with molecular analyses could elucidate these inter-specific relationships.

The distribution of individual Bolboschoenus species related to phytogeographical regions corresponds to their total area of distribution and their ecology; the northwestern part of Iran (the Hyrcanian region - Euro-Siberian region, Euxino-Hyrcanian Province), represented by the Caspian Sea coast and adjacent regions, is characterized by a humid climate and more moderate temperatures. The continental climate, however, widely ranging in temperature with a rainy spring and early summer, is typical of the Irano-Turanian region, and a sub-tropic climate characterizes the Saharo-Sindian region in the southern part of the country (Jalili and Jamzad 1999). The species B. maritimus and B. planiculmis, with their centers of distribution in the temperate belt of Europe and Asia, are concentrated to northwestern part of Iran and there reach the southeastern border of their area. A considerable shift to high altitudes may be seen, especially in B. maritimus compared to its habitats in Europe. Bolboschoenus glaucus, distributed from the Mediterranean region to southern Asia, is a thermophilous species and frequent over all of the phytogeographical regions of Iran, having evidently found very suitable habitats there. Bolboschoenus affinis is a rare species typical of the Irano-Turanian region, similar to B. schmidii. It is not excluded that their recent localities represent relics of former climatic periods.

Acknowledgements - Our sincere thanks are due to the curators of the herbarium collections listed above for making it possible for us to study their Bolboschoenus specimens. We also thank I. V. Tatanov for valuable discussions and for providing scanned copies of $B$. affinis and B. popovii type specimens, our colleagues Zdeněk Kaplan and Jiř́ Sádlo for the collection of Bolboschoenus plants during their travel to Iran, Petr Zákravský for technical assistance during the preparation of the manuscript and Eva Zamazalová and Vladimíra Musilová for the careful planting of cultivated plants. We acknowledge Pertti Uotila for reading the manuscript and correcting the text, for many valuable recommendations and especially for the information about the technical error in the description of $B$. maritimus in 'Flora Iranica'. Our work was financially supported by grants from the Grant Agency of the Academy of Sciences of the Czech Republic (grant no. A 6005905) and the Academy of Sciences of the Czech Republic (grant no. AV0Z 60050516) to ZH, and by the Ministry of Education, Youth and Sports of the Czech Republic (grant no. 0021620828) to KM.

\section{References}

Amini Rad, M. 2003. Two new records of Cyperaceae family from Iran. - Iranian J. Bot. 10: 31-34.

Amini Rad, M. and Hroudová, Z. 2007. Two new records of Bolboschoenus species from Iran. - Iranian J. Bot. 13: 57-62.

Boissier, E. 1882. Flora orientalis. Vol. 5. - H. Georg and Eumdem.

Browning, J. and Gordon-Gray, K. D. 1993. Studies in Cyperaceae in southern Africa. 21. The taxonomic significance of the achene and its embryo in Bolboschoenus. - S. Afr. J. Bot. 59: 311-318.

Browning, J. and Gordon-Gray, K. D. 1999. The inflorescence in southern African species of Bolboschoenus (Cyperaceae). - Ann. Bot. Fenn. 36: 81-97.

Browning, J. and Gordon-Gray, K. D. 2000. Patterns of fruit morphology in Bolboschoenus (Cyperaceae) and their global distribution. - S. Afr. J. Bot. 66: 63-71.

Browning, J. et al. 1995. Achene structure and taxonomy of North American Bolboschoenus (Cyperaceae). - Brittonia 47: 433445.

Browning, J. et al. 1996. Bolboschoenus yagara (Cyperaceae) newly reported for Europe. - Ann. Bot. Fenn. 33: 129-136.

Browning, J. et al. 1997a. Achene morphology and pericarp anatomy of the type specimens of the Australian Bolboschoenus (Cyperaceae). - Austr. Syst. Bot. 10: 49-58.

Browning, J. et al. 1997b. Bolboschoenus maritimus s.l. in the Netherlands: a study of pericarp anatomy based on the work of Irene Robertus-Koster. - Ann. Bot. Fenn. 34: 115-126.

Browning, J. et al. 1998. Bolboschoenus glaucus (Cyperaceae), with emphasis upon Africa. - Nord. J. Bot. 18: 475-482.

Carey, W. and Wallich, N. (eds) 1820. Flora indica. Vol. 1. - Serampore.

DeFilipps, R. A. 1980. Scirpus L. - In: Tutin, T. G. et al. (eds), Flora Europaea. Vol. 5. Cambridge Univ. Press, pp. 277-280. 
Drobov, V. P. 1913. K sistematike roda Bolboschoenus Palla (Scirpus L. ex parte) i ego rasprostraneniya v Sibiri. - Trudy Bot. Muz. Akad. Nauk 11: 86-96, in Russian.

Egorova, T. V. 1967. Bolboschoenus Palla. - In: Egorova T. V. (ed.), Rasteniya Tsentralnoi Azii. Vol. 3. Nauka, p. 19-22, in Russian.

Egorova, T. V. 1976. Bolboschoenus. - In: Fedorov A. A. (ed.), Flora Evropeiskoi chasti SSSR. Vol. 2. Nauka, pp. 93-96, in Russian.

Egorova, T. V. and Tatanov, I. V. 2002. Bolboschoenus glaucus (Lam.) S. G. Smith - novyi vid dlya flory Kavkaza. - Novosti Sist. Vyssh. Rast. 34: 34-42, in Russian.

Egorova, T. V. and Tatanov, I. V. 2003. O sistematicheskom polozhenii Bolboschoenus planiculmis i Bolboschoenus koshewnikowii (Cyperaceae). - Bot. Zhurn. 88: 131-142, in Russian with English summary.

Eig, A. 1931-1932. Les éléments et les groups phytogéographiques auxiliaires dans la flore palestinienne, 2 pts. - Feddes Rep. Spec. Nov. Regn. Veg. Beihf. 63: 1-201.

Govaerts, R. and Simpson, D. A. 2007. World checklist of Cyperaceae, Sedges. - Kew Publ., R. Bot. Gard.

Grossheim, A. A. 1928. Flora Kavkaza. Vol. 1. - Narodnyi Komissariat Zemledeliya SSSR.

Hallier, E. and Brand, A. 1905. Synopsis der deutschen und schweizer Flora, 3rd ed. - O. R. Reisland.

Hayasaka, E. and Ohashi, H. 2002. Achene gross morphology and pericarp anatomy of Japanese Bolboschoenus (Cyperaceae). - J. Jap. Bot. 77: 9-23.

Hedge, I. C. and Wendelbo, P. 1978. Patterns of distribution and endemism in Iran. - Notes R. Bot. Gard. Edinburgh 36: 441464.

Hejný, S. 1950. Bolboschoenus. - In: Dostál, J. (ed.), Květena ČSR. Vol. 2. Př́rodovědecké nakladatelství, p. 1844.

Hoffman, G. F. 1800. Deutschland Flora, Jahrg. 3, Abteil. 1. - Johann Jacob Palm.

Holub, J. 1973. New names in Phanerogamae 2. - Folia Geobot. Phytotax. 8: 155-179.

Hroudová, Z. et al. 2007a. Taxonomy, distribution and ecology of Bolboschoenus in Europe. - Ann. Bot. Fenn. 44: 81-102.

Hroudová, Z. et al. 2007b. Notes on Bolboschoenus glaucus, a new species to the flora of Portugal. - Portugaliae Acta Biol. 22: 211-220.

Jalili, A. and Jamzad, Z. 1999. Red data book of Iran. - Res. Inst. of Forests and Rangelands.

Køie, M. and Rechinger, K. H. (eds.) 1965. Symbolae Afghanicae. Vol. 6. - Biol. Skr. 14: 1-94.

Kots, A. K. 1882. Spisok rastenii sobrannykh v 1878 godu v Oblasti Voiska Donskago bliz stanitsy Uryupinskoi. - Bull. Soc. Nat. Mosc. 57: 199-221, in Russian.

Koyama, T. 1979. Studies in the Cyperaceae of Thailand. II. Miscellaneous taxa of Fimbristylidae, Rhynchosporeae, Scirpeae and Scleriae. - Brittonia 31: 284-293.

Kozhevnikov, A. E. 1988. Rod Klubnekamysh - Bolboschoenu (Aschers.) Palla. - In: Kharkevich, S. S. (ed.), Sosudistye rasteniya sovetskogo Dal'nego Vostoka. Vol. 3. Nauka, pp. 187-190.

Kukkonen, I. 1996. Notes of the treatment of Cyperaceae for Flora Iranica. - Ann. Naturhist. Mus. Wien, 98B Suppl.: 87-95.

Kukkonen, I. 1998. Cyperaceae. - In: Rechinger, K. H. (ed.), Flora Iranica. No. 173. Akademische Druck- und Verlagsanstalt.

Kukkonen, I. 2001. Cyperaceae. - In: Ali, S. I. and Qaiser, M. (eds), Flora of Pakistan. No. 206, Univ. of Karachi.
Lamarck, J. B. 1791. Tableau encyclopedique et methodique des trois regnes de la nature. Vol. 1. - Chez Pancoucke.

Linnaeus, C. 1753. Species plantarum. - Holmiae, Laurentius Salvius.

Litvinov, D. I. 1919. Spisok rastenii Gerbariya Russkoi flory, izdavaemogo Botanicheskim Muzeem Rossiiskoi Akademii Nauk. Vol. 8. - Bot. Muzei Rossiiskoi Akad. Nauk.

Marhold, K. et al. 2004. The Bolboschoenus maritimus group (Cyperaceae), in central Europe, including B. laticarpus, spec. nova. - Phyton (Horn) 44: 1-21.

Marhold, K. et al. 2006. Typification of three names in the Bolboschoenus maritimus group (Cyperaceae). - Willdenowia 36, special issue: $103-113$.

Mobayen, S. 1975. Rostaniha-e-Iran. Vol. 1. - Tehran Univ., in Persian.

Nilsson, Hj. 1901. Scirpus. - In: Neuman, L. M. (ed.), Sveriges Flora. - Lund, in Swedish.

Norlindh, T. 1972. Notes on the variation and taxonomy in Scirpus maritimus complex. - Bot. Not. 125: 397-405.

Ohwi, J. 1944. Cyperaceae Japonicae II. - Mem. Coll. Sci. Kyoto Univ., Ser. B 18: 1-182.

Ovchinnikov, P. N. (ed.) 1963. Flora Tadzhikskoi SSR. Vol. 2. - Nauka.

Parsa, A. 1950. Flora de I'Iran. Vol. 5. - Mus. d'Hist. Nat. Teheran.

Roemer, J. J. and Schultes, J. A. 1817. Systema vegetabilium. Vol. 2. - J. G. Cotae.

Schmidt, F. 1868. Reisen im Amur-Lande und auf der Insel Sachalin. - Mém. Acad. Imper. Sci. St.-Petersbourg, VII. Sér. T. XII 2: 190-191.

Smith, S. G. 1995. New combinations in North American Schoenoplectus, Bolboschoenus, Isolepis and Trichophorum (Cyperaceae). - Novon 5: 97-102.

Smith, S. G. and Kukkonen, I. 1999. A new lectotype for Scirpus maritimus (Cyperaceae). - Taxon 48: 355-357.

Soják, J. 1983. Fragmenta phytotaxonomica et nomenclatoria 4. - Cas. Nár. Mus., Odd. Př́r. 153: 12-37.

Tatanov, I. V. 2003a. Bolboschoenus schmidii (Cyperaceae), novyi vid dlya flory srednei Azii. - Bot. Zhurn. 88: 97-100, in Russian with English summary.

Tatanov, I. V. 2003b. Kriticheskie zametki o vidakh Bolboschoenus desoulavii (Drob.) A. E. Kozhevnikov i Bolboschoenus yagara (Ohwi) Y. C. Yang et M. Zhan (Cyperaceae). - Novosti Sist. Vyssh. Rast. 35: 51-62, in Russian.

Tatanov, I. V. 2004. Sravnitel'naya karpologiya vidov Bolboschoenus (Cyperaceae) v svyazi s sistematikoi roda. - Bot. Zhurn. 89: 1225-1248, in Russian with English summary.

Tatanov, I. V. 2005. Rod Bolboschoenus (Cyperaceae) vo flore Kavkaza. - Bot. Zhurn. 90: 1573-1580, in Russian with English summary.

Tatanov, I. V. 2007. Taksonomicheskii obzor roda Bolboschoenus (Aschers.) Palla (Cyperaceae). - Novosti Sist. Vyssh. Rast. 39: 46-149, in Russian.

Tolmachev, A. I. (ed.) 1976. Flora severo-vostoka Evropeiskoi chasti SSSR. Vol. 2. - Nauka, in Russian.

Visiani, R. 1842. Flora Dalmatica sive Enumeratio stirpium vascularium quas hactenus in Dalmatia lectas et sibi observatas descripsit digessit rariorumque iconibus illustravit. - Apud Fredericum Hofmeister.

Willdenow, C. L. 1809. Enumeratio plantarum horti regii botanici berolinensis. - In taberna Libraria Scholae realis.

Zohary, M. 1963. On the geobotanical structure of Iran. - Bull. Res. Coun. Isr. Suppl. 11D. 